Article

\title{
Serpentinization and weathering of peridotite: A study on the mineralogical and geochemical evolution of the Sta. Cruz nickel laterite deposit, Zambales, Philippines
}

\author{
Karmina Aquino ${ }^{1,2 *}$, Carlo Arcilla ${ }^{2,3}$, Christian Schardt ${ }^{4}$ and Carmela Tupaz ${ }^{5}$ \\ 1 Department of Earth Sciences, Eidgenössische Technische Hochschule Zürich (ETH Zürich) - \\ Sonneggstrasse 5, 8092 Zürich, Switzerland \\ 2 National Institute of Geological Sciences, University of the Philippines - Diliman, Velasquez St, Diliman, \\ Quezon City 1101, Philippines \\ 3 Department of Science and Technology - Philippine Nuclear Research Institute, Diliman, Quezon City 1101, \\ Philippines; caloy.arcilla@gmail.com \\ 4 Artec Umweltpraxis GmbH - Fabrikgasse 2, 08294 Lößnitz, Germany; schardt07@gmail.com \\ 5 Faculty of the International Resource Sciences, Akita University, Akita 010-8502, Japan; catupaz@gipc.akita- \\ u.ac.jp \\ * Correspondence: karmina.aquino@erdw.ethz.ch
}

\begin{abstract}
While there are extensive studies on the mineralogy and geochemistry of laterites worldwide, the temporal and spatial mineralogical development of a typical nickel laterite profile is still poorly constrained. In this study, we present a detailed mineralogical and geochemical characterization of samples systematically collected from a nickel laterite profile at the Sta. Cruz nickel laterite deposit, Zambales, Philippines, to describe the temporal and spatial development of the laterite profile. Wavelength-dispersive X-ray fluorescence spectroscopy (WDSXRF), mass balance-element mobility calculations, transmitted and reflected light microscopy, and previously reported results from coupled X-ray diffraction (XRD) and Rietveld refinement analyses, reveal that the laterite profile investigated is composed of two main horizons: the limonite and saprolite zones, separated by a thin transitional zone. The main zones are further subdivided into subzones based primarily on the mineral assemblage and major element chemistry: upper limonite, lower limonite, transitional zone, upper saprolite, and lower saprolite. Late-stage Ni-rich serpentine veins were observed cutting the upper and lower saprolite subzones. Investigation of the structure of goethite within the limonite zone via Rietveld refinement show that the crystallinity of goethite decreases with increasing Ni content and increasing crystallite size. This suggests that upwards through the limonite zone, as goethite ages, its crystallinity increases which possibly results in the removal of Ni from its crystal structure and eventual remobilization to the lower laterite zones. We propose a genetic model of the formation of the Sta. Cruz laterite consisting of four stages: (1) early-stage alteration, (2) continued serpentinization and volume expansion, (3) late stage serpentinization, dissolution, and incipient oxide formation, and (4) goethite ageing and Ni-rich serpentine vein formation. Overall, our results suggest that serpentinization is an important aspect of Ni laterite formation, both before and after the emplacement of the peridotite protolith.
\end{abstract}

Keywords: Nickel laterites; laterization; serpentinization; weathering; goethite ageing

\section{Introduction}

Serpentinization results whenever Mg-silicates, typically olivine and, less commonly, pyroxene, comprising ultramafic rocks react with water to form serpentine, brucite, and/or magnetite via the following generalized reaction [1]:

$$
\text { Olivine } \pm \text { orthopyroxene }+\mathrm{H}_{2} \mathrm{O} \rightarrow \text { serpentine } \pm \text { brucite }+ \text { magnetite }+\mathrm{H}_{2} \text {. }
$$


Serpentinization occurs in various tectonic settings wherever water ingress into ultramafic rocks facilitated by fractures or faults is possible, including at/near mid-ocean ridges, subduction forearc regions, fracture zones, and in ophiolite complexes on land [1-7].

Tectonic emplacement of the variably serpentinized ultramafic host rock on land and subsequent chemical weathering under humid tropical to subtropical conditions result in the formation of nickel laterite deposits [8-14]. Nickel laterites typically occur as weathering mantle over ophiolite complexes, as well as komatiites and layered complexes in Archean to Phanerozoic stable cratonic platforms [9,12]. Nickel laterite deposits have a characteristic profile (from the bottom to the top): (1) bedrock consisting of partially altered ultramafics, (2) a silicate or saprolite zone, which holds the highest Ni content and is characterized by Mg-silicates such as serpentine, talc, and garnierite; and (3) an oxide or limonite zone, predominantly composed of iron oxyhydroxides, principally goethite, hematite, and maghemite [8-13]. Garnierite is a general term for a distinctively green neoformed mineral assemblage or mixture of three solid solutions of $\mathrm{Mg}-\mathrm{Ni}$ silicates of varying structures: a) serpentine-like type $(7 \AA)$ lizardite-nepouite $\left(\mathrm{Mg}, \mathrm{Ni}_{3} \mathrm{Si}_{2} \mathrm{O}_{5}(\mathrm{OH})_{4}, \mathrm{~b}\right)$ hydrated talc-like type $(10 \AA)$ kerolite-pimelite $(\mathrm{Mg}, \mathrm{Ni})_{3} \mathrm{Si}_{4} \mathrm{O}_{10}(\mathrm{OH})_{2} \cdot \mathrm{H}_{2} \mathrm{O}$, and c) sepiolitelike type $(12 \AA)$ sepiolite-falcondoite $\left(\mathrm{Mg}, \mathrm{Ni}_{8} \mathrm{Si}_{12} \mathrm{O}_{30}(\mathrm{OH})_{4} \cdot 8 \mathrm{H}_{2} \mathrm{O}\right.$ [15-20]. They are Ni-rich and typically occur as veins along joints and shear zones, as matrix within breccias, as well as coatings on saprolite blocks [11,12].

Serpentinization reactions are associated with the generation of hydrogen, methane, and other short-chain hydrocarbons which provide carbon and energy sources for microbial communities [4,21-26]. Because of this, and the abundance of ultramafic rocks in the Archean Earth [27], serpentinization systems have been important study sites for the biogeochemical origin of life on Earth and even other planets [28,29]. Until recently [30-32], most studies about serpentinization focus on the relatively higher temperature $\left(>100^{\circ} \mathrm{C}\right)$ processes, while low temperature serpentinization, in particular its relationship and continuity to the chemical weathering of ultramafic rocks exposed on land, have not received as much attention. An earlier work has suggested that Fe-Ni serpentine formation in Ni-laterites is thermodynamically possible at atmospheric temperatures and pressures [33], highlighting that serpentinization may occur contemporaneously with chemical weathering outside hydrothermal conditions. Accordingly, serpentinization at near surface low temperature conditions has been reported in multiple studies [34-36]. Complete laterite profiles preserve spatio-temporal information [10] on the mineralogy and geochemistry of these rocks as they undergo serpentinization and weathering of ultramafic rocks and are thus key sites for understanding the link between these two processes.

An earlier study [37] emphasizes the primary role of "goethite ageing" with the downward decrease in the bulk Ni content within the limonite of lateritic ores from New Caledonia. Goethite ageing refers to the upward increase in crystallinity of goethite within the limonite zone resulting from the expulsion of Ni from the crystal structure of goethite. Nickel is then either leached from the limonite or is sorbed on the surface of goethite crystals. This is supported by Kuhnel et al. [38] and Trescases [39], who observed a decrease in the crystallinity of goethite with increasing depth. These results suggest that as the nickel laterite profile evolves, goethite crystallinity increases, and nickel content decreases upward through the profile. Goethite ageing is therefore an important aspect of the evolution of the nickel laterite profile.

Here, we investigate samples collected from a nickel laterite profile from the Zambales Ophiolite, Philippines. We aim to describe the evolution of the mineralogy and geochemistry as primary bedrock minerals, such as olivine and orthopyroxene, undergo serpentinization and laterization. In addition, we confirm previous work on goethite ageing [37-39] and show that small changes in the structure of goethite within the limonite zone is related to its nickel content and to the overall evolution of the laterite profile. We propose a conceptual spatio-temporal model of laterization, highlighting key reactions 
linking serpentinization and weathering, which will better constrain the genesis of this economically significant deposit.

\subsection{Zambales Ophiolite Complex}

The Zambales ophiolite complex (ZOC), located in Zambales, Philippines (Figure 1a), is a generally $\mathrm{N}-\mathrm{S}$ trending, east dipping complete ophiolite suite comprised of a succession of volcanic rocks, dike-sill complexes, ultramafic and mafic cumulates, residual harzburgite, and lherzolites [40-43]. The ZOC is subdivided into three massifs from north to south: the Masinloc, Cabangan, and San Antonio massifs, with each massif separated by west-northwest fault boundaries [44,45]. The Masinloc massif is made up of two blocks: the Acoje block in the north and the Coto block in the south. The Acoje block and the San Antonio massif are compositionally similar, having an island arc tholeiite (IAT) affinity, whereas the Coto block and the Cabangan massif have a signature transitional from a mid-ocean ridge basalt to island arc (MORB-IA) [41,45]. The ZOC has been dated Eocene, based on the fossil assemblage of the overlying Aksitero formation [46,47]. Direct radiometric dating of various units from the ZOC concurs with the Late Eocene age of the Aksitero formation and yielded a Middle Eocene age for the ophiolite $[48,49]$. Schweller et al. [50] suggest an early Miocene eastward tilting and erosion of the ZOC, likely related to the subduction initiation along the ancestral Manila Trench. The Eocene age of the ophiolite implies that it is 10-15 Ma years older than the South China Sea (SCS) crust [51], suggesting that it cannot originate from the SCS [48].
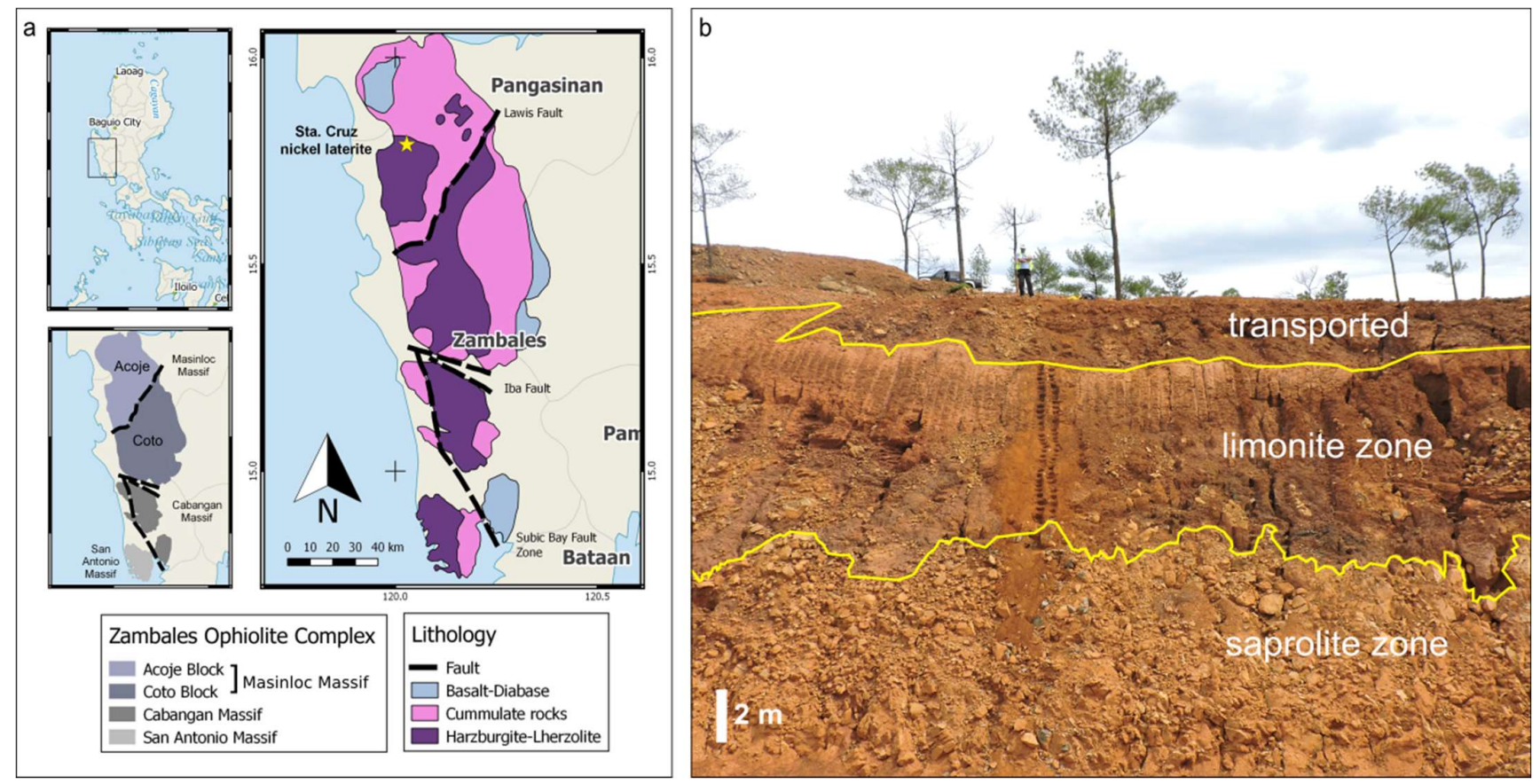

Figure 1. (a) Location of the study area. The Zambales Ophiolite Complex is in west Central Luzon, Philippines. It is subdivided into three massifs, the Masinloc, Cabangan, and San Antonio Massifs separated by west-northwest fault boundaries. The Masinloc massif is subdivided into the Acoje and Coto Blocks. Yellow star indicates the location of the Sta. Cruz nickel laterite deposit. (b) Photo of the nickel laterite profile investigated. The saprolite zone is overlain by the limonite zone. The top most unit is a mechanically transported layer and is therefore not sampled for this study. Modified from Aquino et al. [52].

\subsection{Sta. Cruz nickel laterite deposit}

The Sta. Cruz nickel laterite deposit formed from the weathering of the ultramafic massif of the ZOC Acoje block (Figure 1). The selected nickel laterite profile is located in the municipality of Santa Cruz, in northern Zambales. The deposit is an oxide and hydrous Mg-silicate type deposit [11,12] that exhibits a typical laterite zonation, consisting 

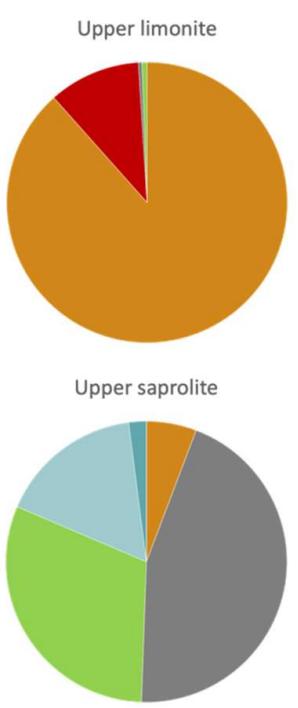

of an upper limonite layer, which is underlain by the saprolite layer, and bedrock. Nickel mineralization in the deposit is associated with the low Ni, high Fe limonite zone and the more extensive low $\mathrm{Fe}$, high Ni saprolite zone [53]. The underlying bedrock is harzburgite with sporadic dunite lenses and minor chromite.

The nickel laterite profile investigated (Figure $1 \mathrm{~b}$ ) is approximately $12 \mathrm{~m}$ high and composed of two main units - an upper limonite zone $(\sim 7 \mathrm{~m})$, and a lower saprolite zone $(\sim 5 \mathrm{~m})$, as well as a thin transitional zone $(\sim 10 \mathrm{~cm})$, each characterized by a distinct set of physical, mineralogical, and geochemical properties. The detailed mineralogy of this outcrop can be found elsewhere $[52,54]$ and is summarized in Figure 2. Previous works have reported the occurrence of "garnierite veins" cutting the lower and upper saprolite subzones of the deposit. As these veins are composed mostly of serpentine and are not a mixture of serpentine-, talc-, and sepiolite-like Mg silicates [14-18], we refer to these veins as $\mathrm{Ni}$-rich serpentine veins instead of the earlier reported "garnierite veins".

\section{Materials and Methods}

Soil samples from the limonite and transitional zones and rock samples from the saprolite zone were collected from the nickel laterite outcrop described above (Figure 1b). The topmost $2 \mathrm{~m}$ of the outcrop are composed of mechanically transported materials and were not sampled for this study. Depths presented in Tables 1 and 2 and discussed throughout this paper is measured with respect to the top of the upper limonite zone. A total of 33 soil samples were collected at an interval of $20 \mathrm{~cm}$, while 13 rock samples were collected at an interval of $50 \mathrm{~cm}$. Samples collected near the transition zone between the limonite and saprolite zones (i.e., at 6.4 to $6.5 \mathrm{~m}$ ) were collected at an interval of $10 \mathrm{~cm}$.

\subsection{Petrographic analysis}

Eight polished thin sections of the saprolite samples and the least altered rock were prepared at the Energy Research and Testing Laboratory at the Philippine Department of Energy. Chromite-rich samples (>70 wt\%) from the upper saprolite zone were not selected for microscopy. The samples were observed under transmitted and reflected light using a Truevision petrographic microscope and an Olympus BX53P polarizing microscope equipped with DP74 camera at the University of the Philippines, National Institute of Geological Sciences.
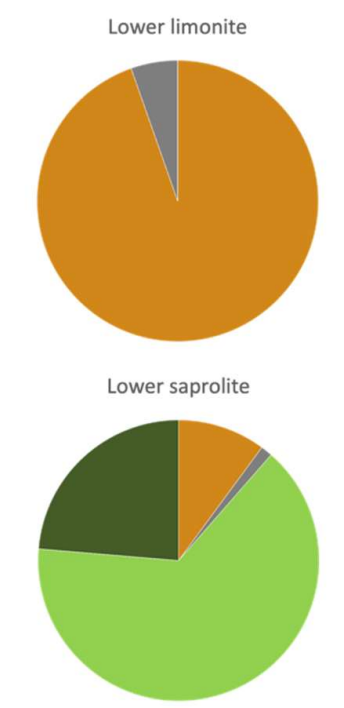
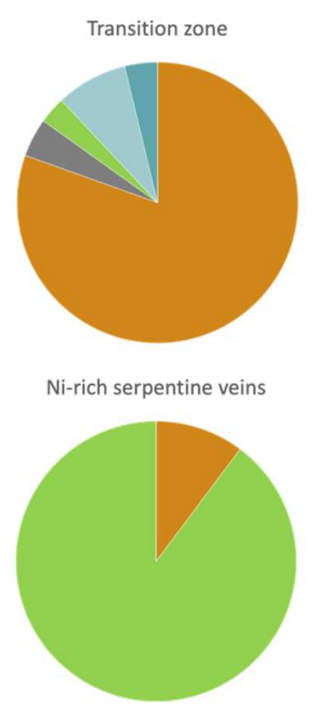
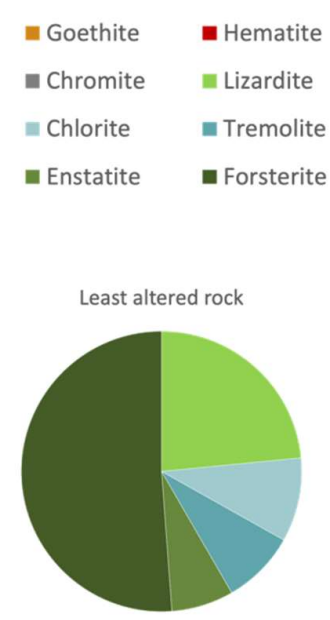

Figure 2. The laterite profile is subdivided into five subzones based on the mineralogy. The topmost zone is the upper limonite subzone, dominated by goethite with minor hematite, and is underlain by the lower limonite subzone composed of goethite and minor chromite. The transition to the saprolite is marked by the first appearance of silicate minerals and a decrease in goethite 
abundance. The saprolite zone is marked by the dominance of Mg-silicates and a decrease in the abundance of goethite. The upper saprolite subzone is comprised mostly of serpentine, with minor chlorite and tremolite. The lower saprolite subzone is distinguished by the presence of relict olivine. The sample taken at a depth of $10.5 \mathrm{~m}$ represents the least altered rock in the profile. This sample is moderately serpentinized ( 40\%) and has significant primary minerals. Lastly, Ni-rich serpentine veins which were incorrectly referred to as "garnierite veins", are composed of about $90 \mathrm{wt} \%$ serpentine and $10 \mathrm{wt} \%$ goethite. Note that abundant chromite of primary origin were observed in the upper saprolite zone. Data are obtained from Aquino et al. [52].

\subsection{X-ray diffraction analysis}

A total of 46 soil and rock samples were prepared for X-ray diffraction analyses. The samples were pulverized to $\sim 200$ mesh $(<0.075 \mathrm{~mm})$ using an agate mortar and pestle, and subsequently oven-dried at $105^{\circ} \mathrm{C}$ for 24 hours. The powdered samples were then packed on a cylindrical top-filled sample holder. The diffractograms of the samples were determined using a Bragg-Bentano Shimadzu XRD-7000 X-Ray Diffractometer with a CuK $\alpha$ radiation at the University of the Philippines, National Institute of Geological Sciences. The samples were analyzed using a step size of $1^{\circ}$ per min at a $3^{\circ}$ to $90^{\circ}$ scan range and voltage of $30 \mathrm{kV}$. The mineral phases were then identified using the PDF4+ Minerals Database by the International Center for Diffraction Data (ICDD), as well as the Materials Data, Inc. MINERAL database [55]. Mineralogical phases were quantified via Rietveld refinement of the diffractograms using the program Siroquant, version 3.0 [52]. Furthermore, the crystallinity of the goethite phase was evaluated by observing the change in the full width at half maximum (FWHM) of the goethite (110) peak. The FWHM was calculated via the Debye-Scherrer equation [56]:

\subsection{Whole rock analyses and loss on ignition}

The samples were pulverized and dried at $105^{\circ} \mathrm{C}$ for a minimum of 6 hours and then cooled in a desiccator. Fused beads for each sample were then prepared using an AFM ModuTemp automated fusion machine. The major and minor element concentrations of the samples were analyzed using a PANalytical Axios PW4400 X-Ray Fluorescence Wavelength Dispersive Spectrometer. Preparation of fused beads, XRF, and loss on ignition (LOI) analysis were performed at the Intertek Testing Services Philippines, Inc.

\subsection{Mass balance calculations}

Mass balance calculations were performed following the methodology of Grant $[57,58]$. Briefly, this method involves the evaluation of the relative changes in the concentration of an altered rock with respect to the parent rock. This is done by plotting the chemical composition of the altered rock $\left(\mathrm{C}^{\mathrm{A}}\right)$ against the composition of the parent rock $(\mathrm{C})$. The isocon is a line defined by one or more immobile species and the origin and has the following equation:

$$
C^{A}=\left(\frac{M^{O}}{M^{A}}\right) C^{O}
$$

Isocons were calculated using Fe as the immobile component, like what has been done in a similar deposit [59]. The relative mass changes of a component can be evaluated as follows:

- Relative mass gain - species plotting above the isocon

- Relative mass loss - species plotting below the isocon.

Additionally, the slope of the isocon gives information on the overall change in the mass relative to the protolith $\left(\mathrm{M}^{\circ} / \mathrm{M}^{A}\right) \cdot 2.5$. Ultramafic index of alteration

For each sample, an Ultramafic Index of Alteration (UMIA) was calculated following the equation defined by Aiglsperger et al. [60]. This chemical alteration index, which is a modified version of the Mafic Index of Alteration (MIA) by Babechuk et al. [61], as well as other previous chemical alteration indices [62,63], quantifies the chemical changes that occur during the chemical weathering process. The UMIA is defined as: 


$$
\mathrm{UMIA}=100 \times\left[\left(\mathrm{Al}_{2} \mathrm{O}_{3}+\mathrm{Fe}_{2} \mathrm{O}_{3(\mathrm{~T})}\right) /\left(\mathrm{SiO}_{2}+\mathrm{MgO}+\mathrm{Al}_{2} \mathrm{O}_{3}+\mathrm{Fe}_{2} \mathrm{O}_{3(\mathrm{~T})}\right)\right]
$$

where molar ratios of the respective major elements are used. The following UMIA values are expected for each of the laterite zones: unweathered peridotite bedrock: $\sim 3$, saprolite: 4-8, limonite: 60-90 [60]. No UMIA values were previously reported for samples taken from the transition zone.

Table 1 Megascopic description of samples from the limonite and transition zones.

\begin{tabular}{|c|c|c|c|c|}
\hline Depth (m) & Zone $^{1}$ & Munsell Color & Descriptive & Short description \\
\hline 0 & $\mathrm{UL}$ & $7.5 Y R$ 5/8 & dark brown & $\begin{array}{l}\text { mostly very fine soil }(<1 \mathrm{~mm}) \text { to coarse frag- } \\
\text { ments }(>10 \mathrm{~mm}) \text { of Fe oxides }\end{array}$ \\
\hline 0.8 & $\mathrm{UL}$ & $5 Y R 4 / 8$ & reddish brown & $\begin{array}{l}\text { mostly very fine to fine soil }(<1 \mathrm{~mm}) \text { to me- } \\
\text { dium fragments }(<5 \mathrm{~mm}) \text { of Fe oxides, slightly } \\
\text { darker red color probably due to presence of } \\
\text { small amounts of hematite }\end{array}$ \\
\hline 1.6 & UL & 5YR 4/8 & reddish brown & $\begin{array}{l}\text { fine to medium }(1-5 \mathrm{~mm}) \text { grained fragments of } \\
\text { Fe oxides; slightly darker red color probably } \\
\text { due to presence of small amounts of hematite }\end{array}$ \\
\hline 2.4 & $\mathrm{UL}$ & 5YR 4/8 & reddish brown & $\begin{array}{l}\text { mostly very fine soil }(<1 \mathrm{~mm}) \text { to coarse frag- } \\
\text { ments }(>10 \mathrm{~mm}) \text { of Fe oxides; slightly darker } \\
\text { red color probably due to presence of small } \\
\text { amounts of hematite }\end{array}$ \\
\hline 3.2 & LL & $5 Y R 4 / 8$ & reddish brown & $\begin{array}{l}\text { mostly medium to coarse grained }(5-10 \mathrm{~mm}) \\
\text { fragments of Fe oxides; slightly darker red } \\
\text { color probably due to presence of small } \\
\text { amounts of hematite }\end{array}$ \\
\hline 4.0 & LL & 7.5YR 5/8 & dark brown & $\begin{array}{l}\text { fine soil }(\sim 1 \mathrm{~mm}) \text { to medium fragments }(<5 \\
\mathrm{mm}) \text { fragments of Fe oxides }\end{array}$ \\
\hline 4.8 & LL & 7.5YR 5/8 & dark brown & $\begin{array}{l}\text { fine soil }(\sim 1 \mathrm{~mm}) \text { to coarse fragments }(>10 \\
\mathrm{mm}) \text { of Fe oxides }\end{array}$ \\
\hline 5.6 & LL & 7.5YR 5/8 & dark brown & $\begin{array}{l}\text { mostly medium to coarse grained }(5-10 \mathrm{~mm}) \\
\text { fragments of Fe oxides }\end{array}$ \\
\hline 6.4 & $\mathrm{~T}$ & 7.5YR 5/8 & dark brown & $\begin{array}{l}\text { poorly sorted mixture of mostly very coarse } \\
\text { grained ( }>30 \mathrm{~mm}) \text { and medium grained (1-5 } \\
\text { mm) Fe oxide-rich rock fragments }\end{array}$ \\
\hline
\end{tabular}

${ }^{1} \mathrm{UL}=$ upper limonite, $\mathrm{LL}=$ lower limonite, $\mathrm{T}=$ transition zone.

\section{Results}

\subsection{Petrography}

Samples from the limonite and transition zones are extremely weathered with no primary minerals or textures observed in hand specimen (Table 1). The saprolite samples are also heavily weathered and serpentinized in hand specimen and thin section (Figures 3-5). Primary minerals, such as olivine and orthopyroxene, are sparse in most samples except for the least weathered sample, N-1050 (Figure 6). These primary minerals are altered mostly to serpentine ( $60-85 \%)$, although poorly crystalline Fe oxides ( $5-15 \%)$ and magnetite (trace), are also present. All samples contain small amounts $(<5 \%)$ of chromite, except for sample N-690 and N-1000. N-690 is adjacent to a chromitite layer located at depths between $6.8 \mathrm{~m}$ and $7.0 \mathrm{~m}$, and thus contains a significant amount of chromite 
( 20\%, Table 2). N-1000 contains visible chromite bands (Figure 3f) in hand specimen. Chromite is a mineral reported to be associated with the peridotite host rock and is therefore of primary origin [41].

At least three types of serpentine, distinguished by their occurrence and association with secondary magnetite, were observed in the saprolite of the Sta. Cruz nickel laterite deposit. Type 1 serpentine (Figures 4-6) exhibits mesh texture and occurs immediately adjacent to partially or completely dissolved relict olivine grains. It is characteristically magnetite-free, or, when present, magnetite occurs only in minor amounts. Moreover, type 1 serpentine is pale green and slightly pleochroic under plane polarized light and exhibits up to $1^{\text {st }}$ order yellow interference colors in crossed polarized light. Type 2 serpentine, on the other hand, occurs as roughly parallel serpentine veins cross cutting type 1 serpentine and is characteristically magnetite and Fe-oxide stain free. They typically occur in the lower saprolite (e.g., N-900; Figure 5). They are colorless in plane polarized light and exhibits almost black interference colors in crossed polarized light. Type 3 serpentine, like type 2, occurs as veins and is typically observed in the upper saprolite. It is often associated with moderate to abundant secondary magnetite, which is usually within the core of the serpentine vein (e.g. N-650; Figure 4). In plane polarized light, type 3 serpentine is colorless to pale greenish yellow and has low relief in crossed polarized light. It exhibits very low interference colors of up to $1^{\text {st }}$ order gray to white.

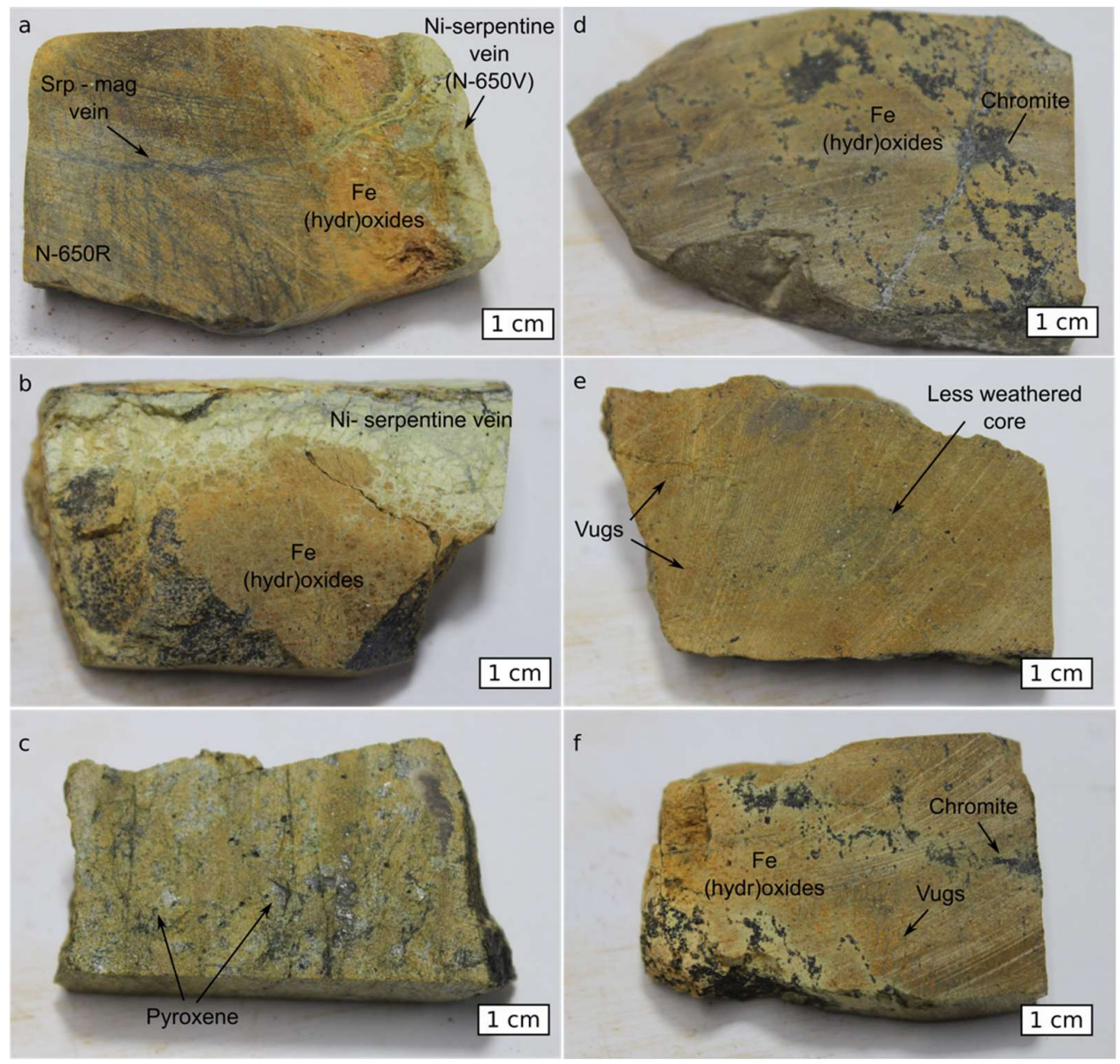

Figure 3. Saprolite samples in hand specimen. (a) Sample N-650R (upper Ni-rich serpentine vein/upper saprolite) showing black serpentine-magnetite veins being altered into light green $\mathrm{Ni}$ rich serpentine-650V. (b) Sample N-1100 (lower Ni-rich serpentine vein/lower saprolite), heavily altered saprolite sample with a Ni-rich serpentine vein. Note that the Ni-rich serpentine vein emanates from what appear to be boundaries of relict grains. (c) Sample N-1050, least altered saprolite 
sample showing pyroxene crystals about 2-3 mm in size. (d) Sample N-690, containing unaltered chromite disseminated in a matrix of strongly weathered to Fe (hydr)oxides. (e) Sample N-850, heavily weathered sample with a less altered core. Small dissolution vugs later filled by $\mathrm{Fe}$ hydr(oxides) are also present. (f) Sample N-1000, showing unaltered disseminated chromite in an Fe hydr(oxide) weathered matrix. Dissolution vugs are also present.

\subsubsection{Petrography of upper saprolite samples}

Samples from the upper saprolite (e.g., N-650R; Figure 4) are strongly weathered and extremely serpentinized (up to $85 \%$ ). Most of the primary minerals are altered to serpentine, $15 \%$ poorly crystalline goethite (amorphous iron oxide), and about $3 \%$ magnetite. Primary minerals, including about $5 \%$ olivine, $2 \%$ tremolite, and trace amounts of orthopyroxenes, are sparse. Olivine crystals, where present, are about 40 to $200 \mu \mathrm{m}$ in size with average size of about $100 \mu \mathrm{m}$, whereas orthopyroxenes are about 200 to $1400 \mu \mathrm{m}$ in size. Dissolution cavities occur within sites of relict primary minerals (Figure 4). In sample N660 , the size of the cavities are approximately 50 to $300 \mu \mathrm{m}$, which are similar in size to the cavities and relict olivine minerals observed in sample N-650R. These cavities are often filled partially or completely with secondary, poorly crystalline goethite \pm amorphous silica (Figure 4c-f). Serpentine occurs both as vein-type serpentine (type 3), as well as meshtype serpentine (type 1) around completely or partially dissolved olivine crystals. In some samples, serpentine exhibits a strong heterogenous and patchy Fe-oxide staining.

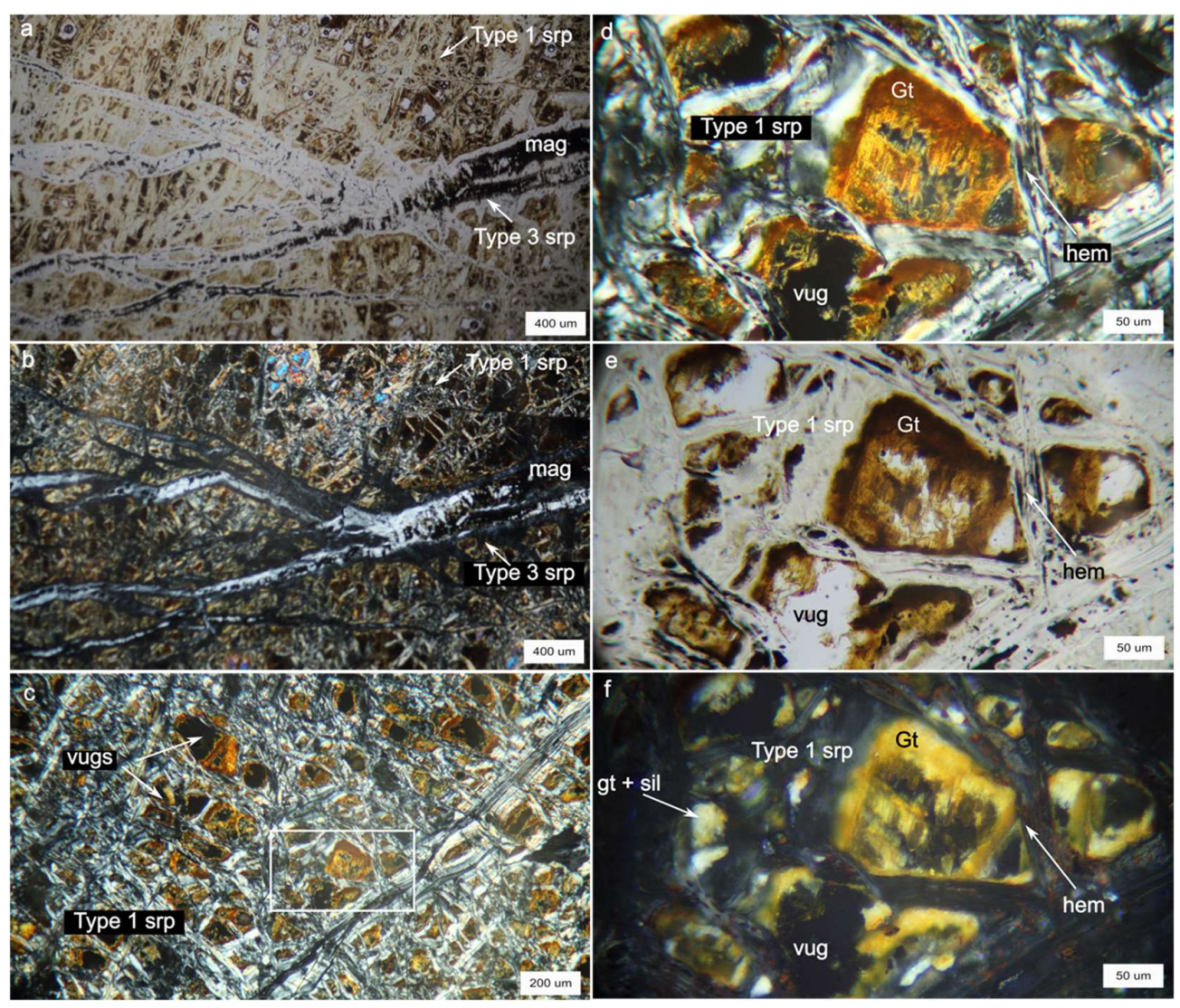

Figure 4. Upper saprolite sample N-650R in thin section. (a) Sample N-650R is a heavily serpentinized rock with almost no primary olivine remaining. Type 1 (mesh type) serpentine (srp) surrounding partially or completely dissolved olivine, crosscut by later type 3 (vein type, magnetiterich) serpentine in plane polarized transmitted light. (b) Same as (a) in crossed polarized transmitted light. (c) Occurrence of poorly crystalline Fe-oxides (gt), as well as minor amorphous silica (sil), as precipitates within dissolution vugs after olivine, in crossed polarized transmitted light. (d) Detail of white box in (c), showing a dissolution vug filled with Fe-oxides. Surrounding 
mesh serpentine (type 1) contains minor hematite (hem), likely from oxidation of magnetite. (e) Same as (c) in plane polarized transmitted light. (f) Same as (c) in crossed polarized reflected light, showing bright orange internal reflections of poorly crystalline Fe-oxides, red internal reflections of hematite, and white internal reflections of amorphous silica.

\subsubsection{Petrography of lower saprolite samples}

Samples from the lower saprolite zone (Figure 5) are less serpentinized ( $60 \%)$ than the upper saprolite samples. Primary minerals, mostly olivine, are more abundant (up to $30 \%$ ) and occur as $2-4 \mathrm{~mm}$-sized groups of optically continuous crystals, with each individual fragment about 30 to $300 \mu \mathrm{m}$ in size. Minor minerals include chromite (5\%), as well as amorphous Fe oxides, and trace amounts of magnetite. In sample N-750, serpentine occurs both as vein type and mesh type (type 1), with the vein type serpentine associated with fillings of magnetite (type 3). Samples taken from the deeper sections (e.g., N-900) are observed to contain both mesh type (type 1) and magnetite-free, subparallel serpentine veins (type 2) (Figure 5c-d). Throughout the lower saprolite, olivine crystals show dissolution features and, in places, are observed to be directly altered to brown Fe-oxides (Figure 5). Poorly crystalline goethite imparts a generally brown tinge in the lower saprolites sample as a result of either direct replacement of partially dissolved olivine, (i.e., as discoloration in minerals) or infills within dissolution cavities.

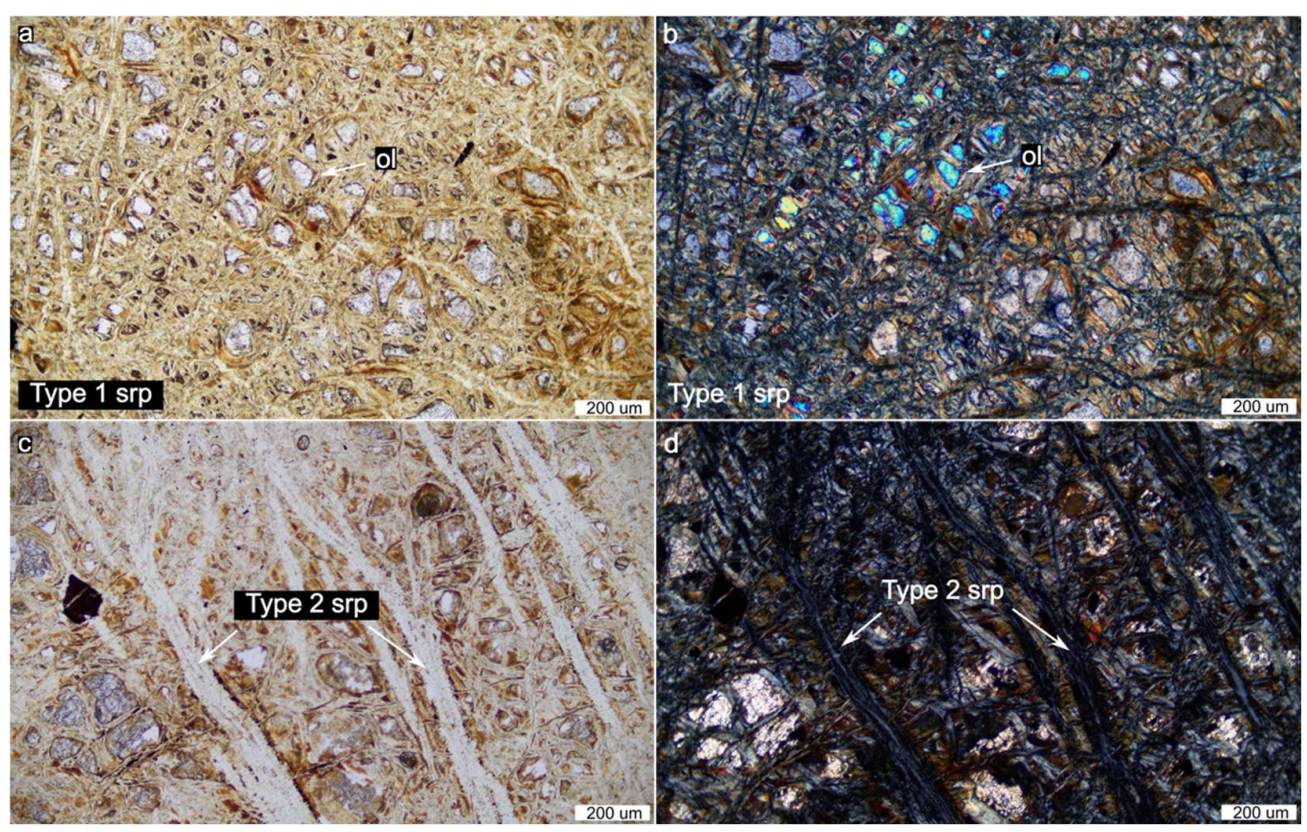

Figure 5. Thin section of samples from the lower saprolite. (a) Sample N-750 is strongly serpentinized and contains a significant amount of primary olivine fragments in optical continuity. Note the brown discoloration on some of the type 1 serpentines, likely due to the presence of Fe-oxide. (b) Same as (a) in crossed polarized transmitted light. (c) N-900 showing roughly parallel serpentine veins (type 2 serpentine) free from Fe-oxide discoloration. Also shown are partially dissolved relict olivine grains. (d) Same as (c) in crossed polarized transmitted light. 


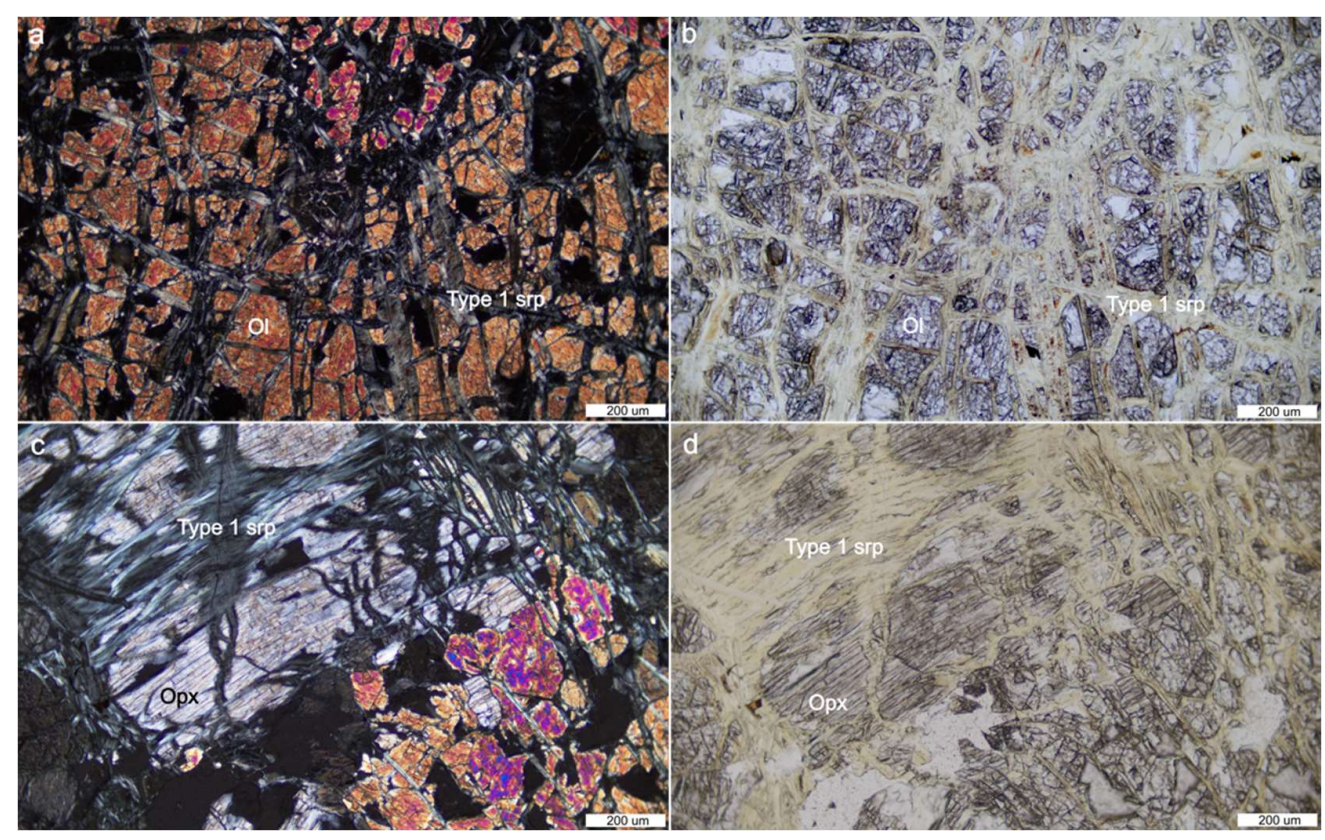

Figure 6. Photomicrographs of the least altered rock in the profile investigated. (a) Olivine cut by cross-cutting serpentine veins in transmitted plane polarized light and (b) in crossed polarized light. (c) Pyroxene is also partially serpentinized parallel to its cleavage planes, in transmitted plane polarized light. (d) Same as (c) in crossed polarized transmitted light.

\subsubsection{Petrography of the least altered rock}

Sample N-1050 represents the least altered rock in the profile (Figure 6). The sample is moderately serpentinized and contains about $40 \%$ serpentine but is also composed of abundant primary minerals including about $50 \%$ olivine, $10 \%$ pyroxene, and trace amounts of chromite. Olivine is fragmented and is cut by cross cutting vein type serpentine, forming isolated fragments about 100 to $200 \mu \mathrm{m}$ in size in optically continuous groups of about 2 to $4 \mathrm{~mm}$. The olivine surface is rough and dissolved, as clearly seen in plane polarized transmitted light. Dissolution cavities are also present locally in the sample and have not yet been filled with any secondary material. Unlike in other samples, olivine crystals are colorless with minimal alteration to Fe-oxides. The serpentine veins are also colorless and do not seem to have Fe-oxide staining. Pyroxene minerals are preserved in this sample and occur as large crystals more than $4 \mathrm{~mm}$ in size, often cut by serpentine parallel to cleavage traces (Figure 6). 

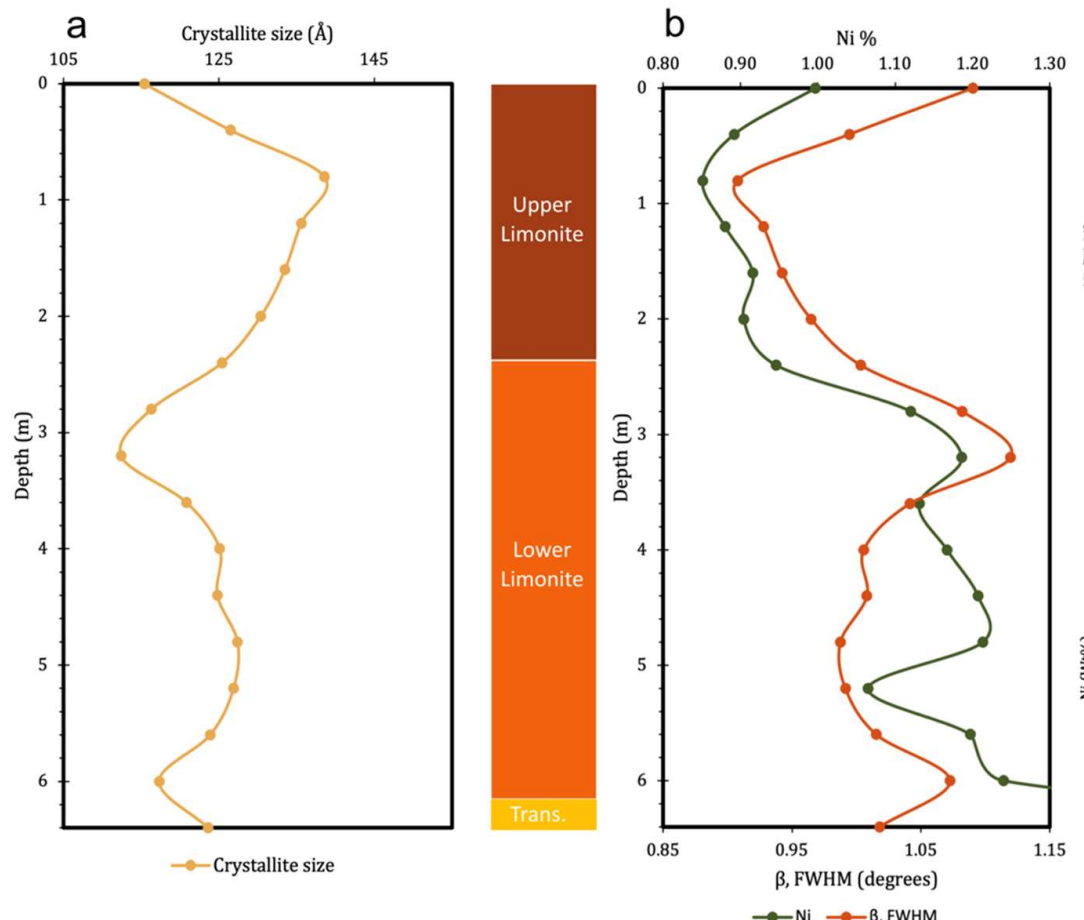

C
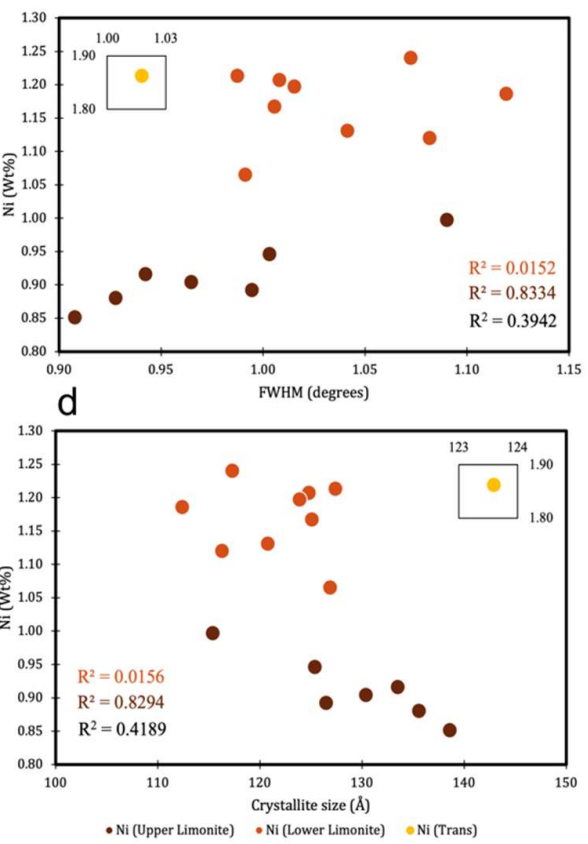

Figure 7. (a) Variations in crystallite size of goethite in the limonite and transition zones with depth, as calculated via Rietveld refinement. (b) Bulk Ni content and calculated full-width at half maximum values of goethite in the limonite and transition zones with depth. (c) Relationship of bulk Ni content and full-width at half maximum (FWHM) of goethite and (d) bulk Ni content and crystallite size of goethite in the limonite and transition zones. Also shown are the $\mathrm{R}^{2}$ values of the samples from the upper limonite (red), lower limonite (orange), and whole limonite (black) zones.

\subsection{Goethite crystallinity and crystallite size measurements}

Crystallite size measurements of the goethite phase obtained from Rietveld refinement of the limonite layer reveal a generally decreasing trend with depth (Figure 7a). Goethite crystallite sizes, which initially increase from 115 to $139 \AA$ in the topmost upper limonite, show a pronounce decreasing trend from 139 to $112 \AA$ in the upper limonite (i.e. depths of 0.8 to $3.2 \mathrm{~m}$ ). Towards the mid-lower limonite, at depths of 3.6 to $4.8 \mathrm{~m}$, the crystallite sizes slightly increase in value to $127 \AA$ before it decrease again to $117 \AA$ towards the bottom of the lower limonite. In the transition zone, the value increases again to 124 $\AA$.

The calculated Full-Width at Half Maximum (FWHM) values from the measured crystallite sizes are shown in Figure $7 \mathrm{~b}$. As expected from the Debye-Scherrer equation [56], the crystallite size and the FWHM have an inverse relationship. Thus, a generally increasing trend with depth in the FWHM values is observed for the studied limonite samples. FWHM values first decrease slightly from a value of 1.090 degrees at the uppermost limonite layer $(0 \mathrm{~m})$ to 0.907 degrees at $0.8 \mathrm{~m}$, and then generally increase to a maximum of 1.112 degrees at a depth of $3.2 \mathrm{~m}$. The FWHM values decrease slightly again to 0.987 degrees at $4.8 \mathrm{~m}$ and decrease again up to 1.073 towards the bottom of the lower limonite at a depth of $6.0 \mathrm{~m}$. 

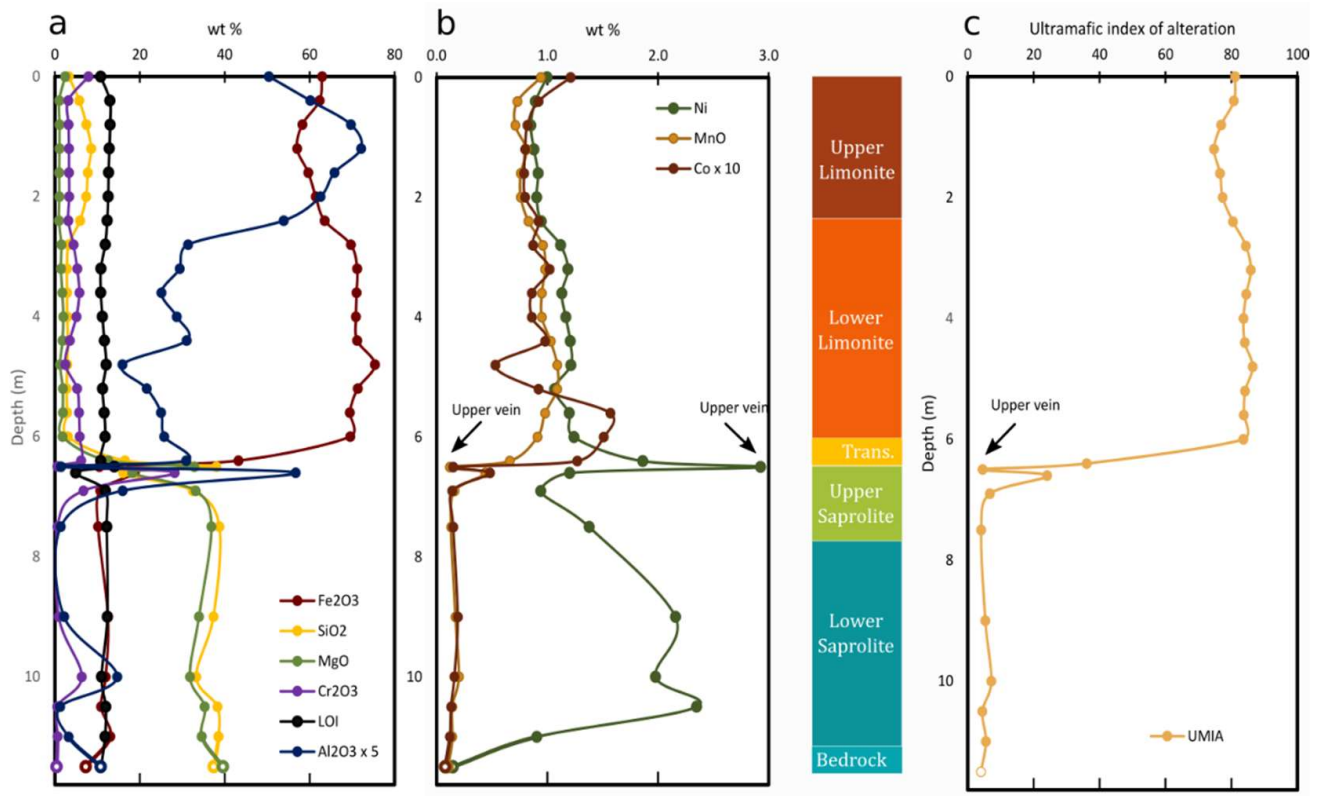

Figure 8. (a) Major and (b) minor element geochemistry of the studied profile and the corresponding laterite horizons. (c) Calculated ultramafic index of alteration (UMIA) as defined by Aiglsperger et al. [60]. Note the relatively high Ni contents and low UMIA of the upper vein.

\subsection{Bulk major and minor geochemistry}

\subsubsection{Limonite zone}

The limonite zone contains elevated $\mathrm{Fe}_{2} \mathrm{O}_{3}$ (up to $75.4 \mathrm{wt} \%$ ) and $\mathrm{Al}_{2} \mathrm{O}_{3}$ (up to 14.4 $\mathrm{wt} \%$ ), and relatively low $\mathrm{MgO}$ (average: $1.5 \mathrm{wt} \%$ ) and $\mathrm{SiO}_{2}$ (average: $4.5 \mathrm{wt} \%$ ) concentrations (Table 2, Figure 8a). Within the limonite, Fe content slightly decreases upwards. Interestingly, the $\mathrm{Al}_{2} \mathrm{O}_{3}$ content of the upper limonite zone is generally higher compared to the lower limonite zone. Within the limonite, the $\mathrm{MgO}$ content slightly increases downwards from an average value of $1.2 \mathrm{wt} \%$ in the upper limonite to $1.7 \mathrm{wt} \%$ in the lower limonite. Contrary to the behavior of $\mathrm{MgO}$ values, $\mathrm{SiO}_{2}$ content shows a decreasing trend downwards within the limonite, with an average value of $6.6 \mathrm{wt} \%$ in the upper limonite to $2.9 \mathrm{wt} \%$ in the lower limonite. Significant concentrations of $\mathrm{Ni}, \mathrm{Mn}$, and $\mathrm{Co}$ are noted in the limonite zone of the investigated profile (Figure $8 \mathrm{~b}$ ). Within the limonite, NiO content ranges from 1.1 to $1.6 \mathrm{wt} \%$ and generally increase with depth. Average values for $\mathrm{MnO}$ and $\mathrm{Co}$ are 0.91 and $0.10 \mathrm{wt} \%$, respectively. Both $\mathrm{MnO}$ and Co show a slightly increasing trend in the limonite zone with depth. $\mathrm{MnO}$ values are enriched up to $1.09 \mathrm{wt} \%$ at the lower limonite while Co values are enriched up to $0.16 \mathrm{wt} \%$ near the transition zone to the saprolite.

\subsubsection{Transition zone, saprolite zone, and Ni-rich serpentine veins}

$\mathrm{Fe}_{2} \mathrm{O}_{3}$ shows a sharp decrease in concentration towards the transition and saprolite zones (average of $43.2 \mathrm{wt} \%$ and $12.5 \mathrm{wt} \%$, respectively; Figure $8 \mathrm{a}$ ). $\mathrm{Al}_{2} \mathrm{O}_{3}$ content in the transition zone is $6.2 \mathrm{wt} \%$, which decreases further to an average of $3.1 \mathrm{wt} \%$ in the saprolite zone. Chromite-rich samples (e.g., N-660; Figure 8a and Table 2) are enriched in $\mathrm{Al}_{2} \mathrm{O}_{3}$ resulting an apparent spike in $\mathrm{Al}$ contents in the upper saprolite zone. From the limonite zone, $\mathrm{MgO}$ and $\mathrm{SiO}_{2}$ increase to values of $12.6 \mathrm{wt} \%$ and $16.5 \mathrm{wt} \%$, respectively in the transition zone and to values of $31.6 \mathrm{wt} \%$ and $32.7 \mathrm{wt} \%$, respectively, in the saprolite zone. $\mathrm{NiO}$ contents is generally more elevated in the saprolite than in the limonite, with values of up to $3.0 \mathrm{wt} \%$ (Figure $8 \mathrm{~b}$ ). $\mathrm{MnO}$ and Co values are generally not as significant within 
the saprolite as in the limonite zone with average values of $0.21 \mathrm{wt} \%$ for $\mathrm{MnO}$ and 0.02 wt $\%$ for Co.

Overall, the two Ni-rich serpentine veins have slightly higher $\mathrm{SiO}_{2}, \mathrm{MgO}$, and $\mathrm{NiO}$ and lower $\mathrm{Fe}_{2} \mathrm{O}_{3}, \mathrm{Al}_{2} \mathrm{O}_{3}$, and $\mathrm{MnO}$ than the average saprolite (Table 2). Interestingly, the $\mathrm{Ni}$-rich serpentine vein sampled at a higher depth has a higher $\mathrm{NiO}$ content than the vein sampled below the lower saprolite. LOI values do not show any significant difference between each laterite horizon, with values ranging from 10.8 to $14.0 \mathrm{wt} \%$ within the profile.

\subsection{Ultramafic index of alteration}

The Ultramafic Index of Alteration (UMIA) values calculated for the Sta. Cruz nickel laterite profile (Table 2, Figure 8c) are generally consistent with expected values [60]. UMIA values in the limonite zone range from 74.7 to 86.5 . The upper limonite has slightly lower UMIA values than the lower limonite. Towards the transition zone, the UMIA values decrease to 36.1 , before decreasing significantly to values $<8$ in the saprolite. There is no significant trend in the UMIA values between the upper and lower saprolite or the Nirich serpentine veins.

Figure 9 shows plots of the Sta. Cruz nickel laterite samples in molar ternary AF-S-M $\left(\mathrm{Al}_{2} \mathrm{O}_{3}+\mathrm{Fe}_{2} \mathrm{O}_{3}-\mathrm{SiO}_{2}-\mathrm{MgO}\right)$ and $\mathrm{A}-\mathrm{SM}-\mathrm{F}\left(\mathrm{Al}_{2} \mathrm{O}_{3}-\mathrm{SiO}_{2}+\mathrm{MgO}-\mathrm{Fe}_{2} \mathrm{O}_{3}\right)$ diagrams, including their corresponding UMIA values. Both diagrams show weathering of an initially $\mathrm{Mg}$ - and Sirich peridotite bedrock towards an Al- and Fe-rich limonite. Figure 9b highlights Fe-enrichment predominant in the Sta. Cruz nickel laterite compared to bauxitization. This observation is supported by the absence of gibbsite in the investigated samples. Moreover, there is a clear separation of the upper and lower limonite samples in both diagrams, indicating that the upper limonite contains relatively more $\mathrm{Al}$ and Si compared to the lower limonite.
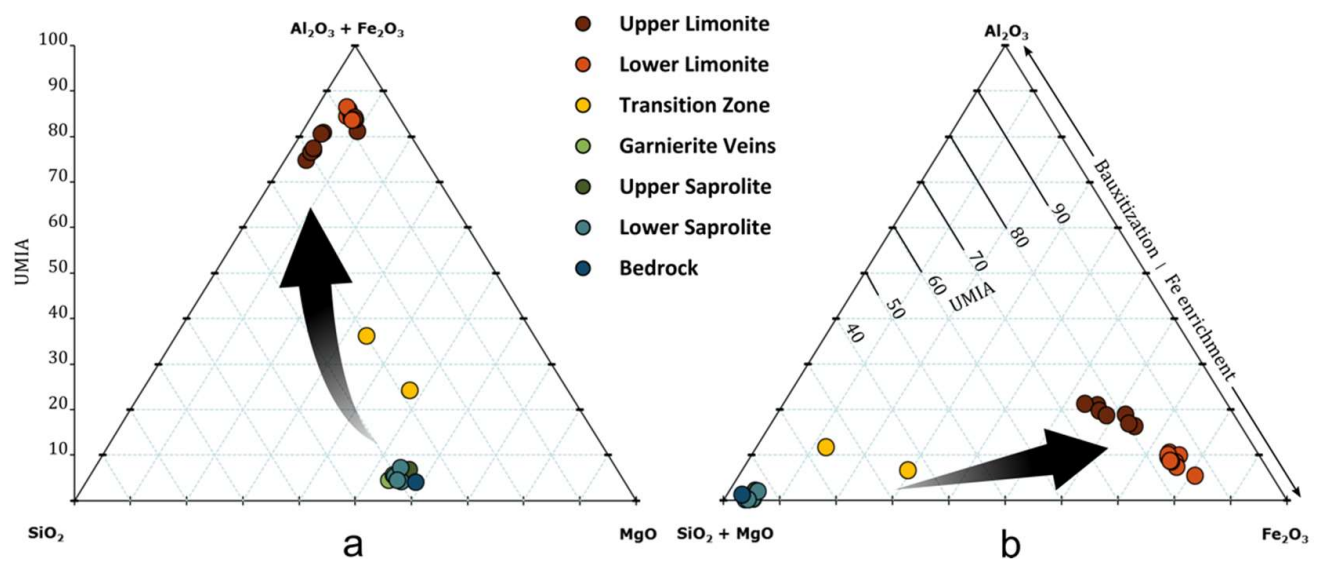

Figure 9. Chemical evolution of the laterite profile during weathering as shown by (a) molar ternary $\mathrm{Al}_{2} \mathrm{O}_{3}+\mathrm{Fe}_{2} \mathrm{O}_{3}-\mathrm{SiO}_{2}-\mathrm{MgO}(\mathrm{AF}-\mathrm{S}-\mathrm{M})$ and (b) molar ternary $\mathrm{Al}_{2} \mathrm{O}_{3}-\mathrm{SiO}_{2}+\mathrm{MgO}_{2}-\mathrm{Fe}_{2} \mathrm{O}_{3}(\mathrm{~A}-\mathrm{SM}-\mathrm{F}$ ) diagrams. Both diagrams show weathering of an initially $\mathrm{Mg}$ - and $\mathrm{Si}$ - rich peridotite bedrock towards an Al- and Fe-rich limonite while (b) highlights that Fe-enrichment is predominant in the Sta. Cruz nickel laterite over bauxitization. Also shown is the Ultramafic Index of Alteration (UMIA) as defined by Aiglsperger et al. [60].

\subsection{Relative mass changes}

Relative mass changes (Figure 10, Table A1) calculated for the studied outcrop is similar to those observed in other laterite deposits [36,59]. The limonite zone is characterized by an almost complete removal of $\mathrm{SiO}_{2}$ (i.e., up to $99 \%$ relative mass loss) and $\mathrm{MgO}$ (up to $100 \%$ mass loss). Ni is also leached by up to about $60 \%$ in the limonite, with the amount of depletion decreasing with depth. $\mathrm{Co}$ and $\mathrm{MnO}$ on the other hand are associated with 
mass gains in the limonite. Co mass gains increase in the lower limonite towards the tran- 32 sition zone. A similar behavior is observed for Mn but to a lesser degree.
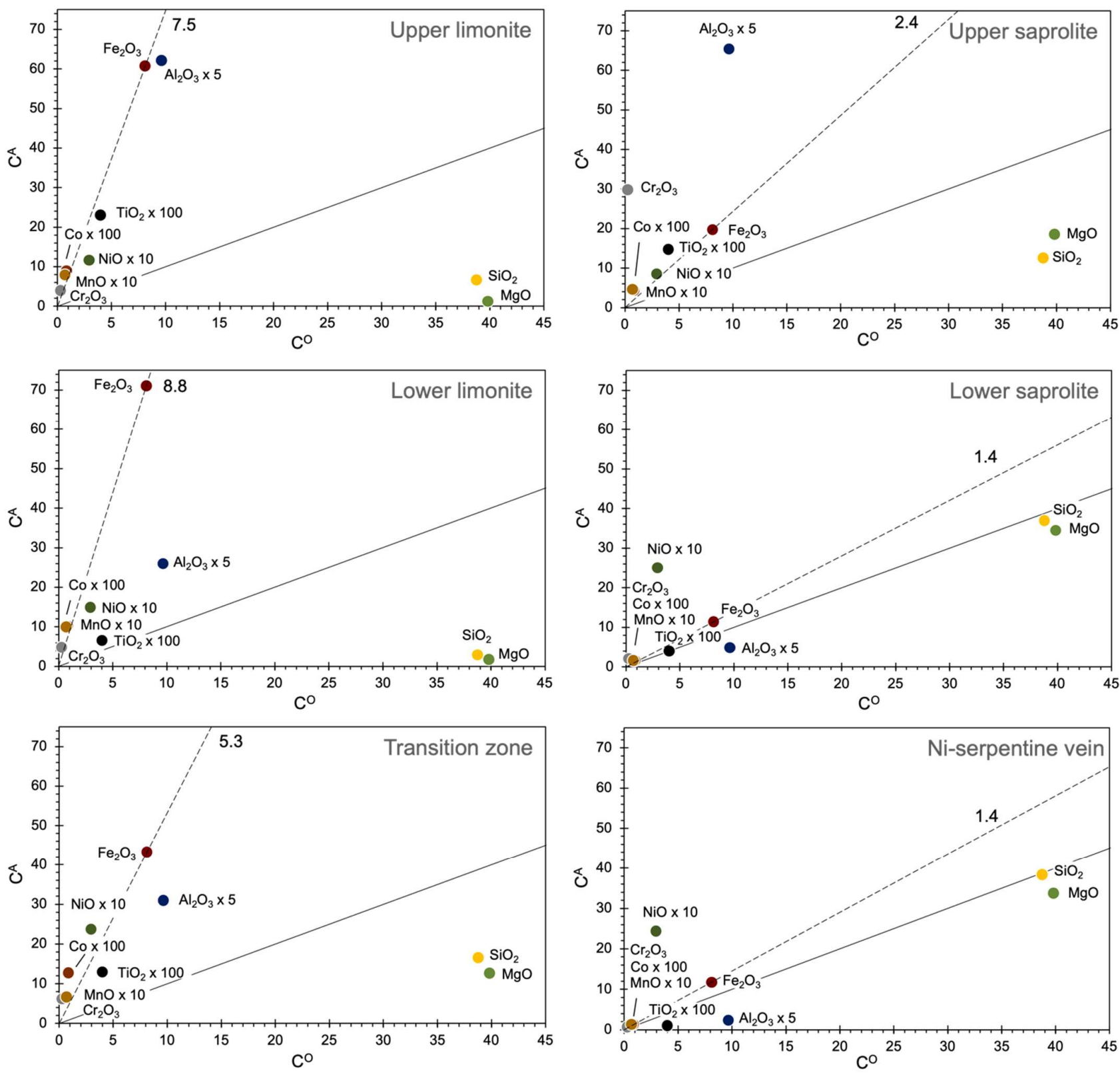

Figure 10. Isocon diagrams for each laterite zone in the outcrop investigated. Altered compositions $\left(\mathrm{C}^{\mathrm{A}}\right)$ are the average composition of the samples from each zone. The composition of the parent rock $\left(\mathrm{C}^{\mathrm{O}}\right)$ is the average composition of two peridotite samples collected near the study area. Dashed line is the isocon defined by the immobile species Fe and the origin. Solid line represents $\mathrm{M} / \mathrm{M}^{\mathrm{A}}=1$. The numbers are the slope of the isocon or $\mathrm{M}^{\mathrm{O}} / \mathrm{M}^{\mathrm{A}}$. Species plotting along the isocon did not change its mass during transformation, species plotting above the isocon experienced mass gains, whereas species plotting below the isocon experienced mass loss during transformation. 
Table 2. Bulk geochemistry and Ultramafic Index of Alteration (UMIA) of samples from the Sta. Cruz nickel laterite. All compositions are in wt\%

\begin{tabular}{|c|c|c|c|c|c|c|c|c|c|c|c|c|c|c|c|c|c|c|c|c|}
\hline Sample & Hori- & Depth & $\mathrm{SiO}_{2}$ & $\mathrm{TiO}_{2}$ & $\mathbf{A l}_{2} \mathbf{O}_{3}$ & $\mathrm{Fe}_{2} \mathrm{O}_{3}$ & $\mathrm{Cr}_{2} \mathrm{O}_{3}$ & MnO & $\mathrm{NiO}$ & Co & MgO & $\mathrm{CaO}$ & $\mathrm{BaO}$ & $\mathrm{Na}_{2} \mathrm{O}$ & $\mathbf{K}_{2} \mathbf{O}$ & $\mathrm{P}_{2} \mathrm{O} 5$ & $\mathrm{SO}_{3}$ & LOI & Total & UMIA \\
\hline $\mathrm{N}-000$ & UL & 0.0 & 3.28 & 0.12 & 10.08 & 62.91 & 7.91 & 0.94 & 1.27 & 0.12 & 2.42 & $<0.01$ & $<0.005$ & $<0.01$ & $<0.01$ & 0.01 & 0.29 & 10.78 & 100.0 & 81.1 \\
\hline $\mathrm{N}-040$ & UL & 0.4 & 5.75 & 0.21 & 12.03 & 62.34 & 3.14 & 0.73 & 1.14 & 0.09 & 1.02 & $<0.01$ & $<0.005$ & 0.02 & $<0.01$ & 0.02 & 0.39 & 12.96 & 99.7 & 80.8 \\
\hline $\mathrm{N}-080$ & UL & 0.8 & 7.43 & 0.29 & 13.94 & 58.27 & 3.23 & 0.71 & 1.08 & 0.08 & 1.09 & $<0.01$ & $<0.005$ & 0.02 & 0.01 & 0.02 & 0.34 & 13.03 & 99.5 & 76.9 \\
\hline $\mathrm{N}-120$ & UL & 1.2 & 8.53 & 0.31 & 14.42 & 57.04 & 3.33 & 0.81 & 1.12 & 0.08 & 1.07 & $<0.01$ & $<0.005$ & $<0.01$ & 0.02 & 0.02 & 0.30 & 12.84 & 99.8 & 74.7 \\
\hline $\mathrm{N}-160$ & UL & 1.6 & 7.74 & 0.26 & 13.17 & 59.67 & 3.33 & 0.76 & 1.17 & 0.08 & 1.01 & $<0.01$ & $<0.005$ & 0.01 & 0.01 & 0.02 & 0.30 & 12.65 & 100.1 & 76.6 \\
\hline $\mathrm{N}-200$ & UL & 2.0 & 7.38 & 0.24 & 12.51 & 61.43 & 3.38 & 0.76 & 1.15 & 0.08 & 1.04 & $<0.01$ & $<0.005$ & $<0.01$ & $<0.01$ & 0.01 & 0.30 & 12.57 & 100.8 & 77.3 \\
\hline $\mathrm{N}-240$ & UL & 2.4 & 5.92 & 0.18 & 10.78 & 63.52 & 3.16 & 0.83 & 1.20 & 0.09 & 0.95 & $<0.01$ & $<0.005$ & 0.02 & $<0.01$ & 0.01 & 0.24 & 12.34 & 99.2 & 80.5 \\
\hline $\mathrm{N}-280$ & LL & 2.8 & 3.27 & 0.08 & 6.27 & 69.67 & 4.38 & 0.96 & 1.43 & 0.09 & 1.51 & $<0.01$ & 0.02 & 0.02 & $<0.01$ & 0.01 & 0.18 & 11.86 & 99.7 & 84.4 \\
\hline $\mathrm{N}-320$ & LL & 3.2 & 2.85 & 0.06 & 5.88 & 71.17 & 5.26 & 0.98 & 1.51 & 0.10 & 1.42 & $<0.01$ & 0.01 & 0.01 & $<0.01$ & 0.01 & 0.17 & 10.84 & 100.2 & 85.9 \\
\hline $\mathrm{N}-360$ & LL & 3.6 & 2.84 & 0.06 & 5.02 & 71.05 & 5.76 & 0.95 & 1.44 & 0.09 & 1.75 & $<0.01$ & 0.01 & 0.02 & $<0.01$ & 0.01 & 0.15 & 10.81 & 99.9 & 84.5 \\
\hline $\mathrm{N}-400$ & LL & 4.0 & 2.90 & 0.06 & 5.74 & 70.90 & 5.06 & 0.95 & 1.49 & 0.09 & 1.99 & $<0.01$ & $<0.005$ & 0.01 & $<0.01$ & 0.01 & 0.16 & 11.19 & 100.5 & 83.7 \\
\hline N-440 & LL & 4.4 & 3.09 & 0.07 & 6.20 & 71.19 & 3.49 & 1.03 & 1.54 & 0.10 & 1.80 & $<0.01$ & $<0.005$ & 0.02 & $<0.01$ & 0.01 & 0.17 & 11.66 & 100.3 & 84.1 \\
\hline N-480 & LL & 4.8 & 2.89 & 0.04 & 3.18 & 75.38 & 2.47 & 1.09 & 1.54 & 0.05 & 1.24 & $<0.01$ & 0.06 & 0.03 & $<0.01$ & 0.01 & 0.14 & 12.07 & 100.1 & 86.5 \\
\hline N-520 & LL & 5.2 & 2.76 & 0.06 & 4.33 & 71.31 & 5.24 & 1.09 & 1.36 & 0.09 & 1.86 & $<0.01$ & 0.03 & 0.02 & $<0.01$ & 0.01 & 0.12 & 11.25 & 99.4 & 84.2 \\
\hline N-560 & LL & 5.6 & 2.86 & 0.08 & 5.00 & 69.43 & 5.70 & 0.98 & 1.52 & 0.16 & 1.86 & $<0.01$ & $<0.005$ & 0.02 & $<0.01$ & 0.01 & 0.13 & 11.65 & 99.2 & 83.8 \\
\hline N-600 & LL & 6.0 & 3.05 & 0.08 & 5.15 & 69.53 & 5.85 & 0.91 & 1.58 & 0.15 & 1.79 & 0.01 & $<0.005$ & $<0.01$ & $<0.01$ & 0.01 & 0.14 & 11.82 & 99.9 & 83.6 \\
\hline $\mathrm{N}-640$ & $\mathrm{~T}$ & 6.4 & 16.48 & 0.13 & 6.18 & 43.23 & 6.16 & 0.66 & 2.37 & 0.13 & 12.57 & 0.65 & $<0.005$ & 0.04 & $<0.01$ & 0.01 & 0.06 & 10.77 & 99.3 & 36.1 \\
\hline $\mathrm{N}-650$ & $\mathrm{~V}$ & 6.5 & 38.04 & $<0.01$ & 0.29 & 10.47 & 0.63 & 0.12 & 3.72 & 0.02 & 32.87 & $<0.01$ & $<0.005$ & $<0.01$ & $<0.01$ & $<0.001$ & 0.02 & 13.98 & 100.1 & 4.5 \\
\hline N-660 & US & 6.6 & 16.07 & 0.09 & 11.34 & 18.84 & 28.16 & 0.44 & 1.53 & 0.05 & 18.24 & 0.16 & 0.01 & 0.18 & $<0.01$ & $<0.001$ & 0.01 & 4.93 & $* 100$ & 24.1 \\
\hline N-680 & US & 6.8 & 0.71 & 0.18 & 19.25 & 24.35 & 42.38 & 0.62 & 0.32 & 0.05 & 11.43 & $<0.01$ & 0.01 & 0.15 & $<0.01$ & $<0.001$ & 0.01 & 0.58 & $* 100$ & 53.6 \\
\hline N-690 & US & 6.9 & 32.52 & $<0.01$ & 3.19 & 10.68 & 6.73 & 0.16 & 1.20 & 0.01 & 33.16 & $<0.01$ & 0.01 & 0.19 & $<0.01$ & $<0.001$ & $<0.001$ & 11.87 & 99.7 & 6.7 \\
\hline N-700 & US & 7.0 & 0.91 & 0.17 & 18.53 & 25.00 & 41.90 & 0.65 & 0.35 & 0.06 & 11.25 & $<0.01$ & $<0.005$ & 0.18 & $<0.01$ & $<0.001$ & 0.03 & 1.04 & $* 100$ & 53.5 \\
\hline $\mathrm{N}-750$ & LS & 7.5 & 38.74 & $<0.01$ & 0.28 & 10.16 & 0.57 & 0.13 & 1.75 & 0.02 & 36.85 & 0.02 & $<0.005$ & 0.01 & $<0.01$ & $<0.001$ & 0.01 & 12.20 & 100.7 & 4.1 \\
\hline N-900 & LS & 9.0 & 37.34 & $<0.01$ & 0.43 & 12.51 & 0.90 & 0.17 & 2.75 & 0.02 & 33.94 & 0.01 & $<0.005$ & $<0.01$ & $<0.01$ & $<0.001$ & 0.01 & 12.36 & 100.4 & 5.3 \\
\hline N-1000 & LS & 10.0 & 33.31 & 0.04 & 2.93 & 11.96 & 6.33 & 0.20 & 2.52 & 0.02 & 31.83 & $<0.01$ & $<0.005$ & $<0.01$ & $<0.01$ & $<0.001$ & 0.01 & 11.01 & 100.1 & 7.2 \\
\hline N-1050 & LS & 10.5 & 38.27 & $<0.01$ & 0.25 & 10.88 & 0.54 & 0.14 & 2.99 & 0.01 & 35.29 & 0.01 & $<0.005$ & $<0.01$ & $<0.01$ & $<0.001$ & 0.01 & 11.98 & 100.4 & 4.5 \\
\hline N-1100 & $\mathrm{V}$ & 11.0 & 38.55 & 0.01 & 0.64 & 13.08 & 0.65 & 0.14 & 1.15 & 0.01 & 34.60 & $<0.01$ & $<0.005$ & $<0.01$ & $<0.01$ & $<0.001$ & 0.01 & 11.82 & 100.7 & 5.6 \\
\hline PH-S-15A & $\mathrm{BR}$ & & 37.42 & 0.04 & 2.16 & 7.29 & 0.19 & 0.08 & 0.19 & 0.01 & 39.61 & 1.99 & 0.01 & $<0.01$ & 0.01 & 0.01 & & 10.89 & 99.9 & 4.0 \\
\hline PH-S-15B & $\mathrm{BR}$ & & 40.13 & 0.04 & 1.70 & 8.93 & 0.36 & 0.06 & 0.40 & 0.01 & 40.05 & 1.49 & $<0.01$ & $<0.01$ & 0.01 & 0.01 & & 7.73 & 100.5 & 4.2 \\
\hline
\end{tabular}


The transition zone is characterized by a slight decrease in the associated $\mathrm{SiO}_{2}$ and $\mathrm{MgO}$ mass loss. Ni starts to experience a slight mass gain $(+27 \%)$ while Co mass gains are the highest around this zone. Towards the saprolite zone, $\mathrm{MgO}$ and $\mathrm{SiO}_{2}$ mass losses decrease to an average of $-35 \%$ and $-30 \%$, respectively. The saprolite zone is also characterized by mass gains of $\mathrm{NiO}, \mathrm{MnO}$, and $\mathrm{Co}$, with the $\mathrm{NiO}$ mass gains reaching up to $+400 \%$. The Ni-serpentine veins observed cross-cutting the saprolite zone is associated with the highest $\mathrm{NiO}$ mass gains of up to more than $+700 \%$.

\section{Discussion}

\subsection{Laterite zonation}

The Sta. Cruz nickel laterite deposit can be divided into two main zones based on mineralogy, geochemistry, and calculated UMIA: an upper limonite layer and a lower saprolite layer, separated by a transition zone. The transition zone is characterized by mineralogy and geochemistry intermediate between the limonite and saprolite layer. The limonite is further subdivided into two layers: upper and lower limonite. Similarly, the saprolite can be divided into upper and lower saprolite zones. Lastly, Ni-rich serpentine serpentine veins were observed cutting the upper and lower saprolite layers.

\subsubsection{Limonite zone}

The limonite zone represents the most evolved layer of the laterite profile investigated, with a UMIA value of 78. It is an Fe- and Al- rich layer, completely devoid of primary minerals and made up of the mineral assemblage goethite+hematite for the upper limonite, and goethite+chromite for the lower limonite. $\mathrm{Mg}$ and $\mathrm{Si}$ are almost completely leached out of this layer with relative mass losses of almost $100 \%$. The upper limonite contains a slightly higher amount of $\mathrm{SiO}_{2}$ than the lower limonite, resulting in a lower UMIA for the upper limonite. This is probably due to the presence of amorphous silica, a common reaction product of weathering, along with amorphous Fe-oxides. Amorphous silica could not be detected by $\mathrm{X}$-ray diffraction due to the absence of a crystalline structure. Within the limonite, $\mathrm{MnO}, \mathrm{NiO}$, and Co generally increase with depth and are enriched in the lower limonite.

Bulk chemistry of the samples reveals a significant amount of $\mathrm{Al}_{2} \mathrm{O}_{3}$ of more than 10 $w t \%$, although Al-bearing minerals, such as gibbsite, were not observed in the limonite zone. Interestingly, the upper limonite zone has a lower Fe content and higher Al content than the lower limonite zone. The higher Al content in the upper limonite correlates with the occurrence of hematite, which may suggest that $\mathrm{Al}$ is hosted in hematite as previously suggested [64,65]. Moreover, goethite with 18\% Al substitution best fits the X-ray diffractogram of samples from the upper limonite [54]. Overall, in the absence of mineral chemistry data, it is inferred here that $\mathrm{Al}$ is hosted in the limonite by goethite and/or hematite.

We hypothesize that $\mathrm{Ni}$ within the limonite is hosted primarily by goethite, with the nickel contents observed to be directly proportional to the FWHM of the goethite (110) peak and inversely proportional to the goethite crystallite size (Figure 7). A stronger correlation $\left(\mathrm{R}^{2}=0.83\right)$ is observed in the upper limonite than in the lower limonite $\left(\mathrm{R}^{2}=0.016\right)$ for both FWHM and crystallite size. One possibility is that Ni is not exclusively hosted by goethite in the lower limonite zone. For example, Mn oxyhydroxides which are often reported in lower oxide zones of $\mathrm{Ni}$ laterites [12] including two other deposits from the Philippines [64,66], can host Ni. In particular, significant amounts of Ni (up to $15.6 \mathrm{wt} \%$ ) has been reported to be associated with Mn oxyhydroxides from the Intex deposit in Mindoro, Philippines [66]. Mn oxyhydroxides are difficult to detect with the methods performed in this paper but the slight increase in $\mathrm{Mn}$ and Co concentrations towards the lower limonite may hint to their presence in the Sta. Cruz laterite. Because phases other than goethite may host $\mathrm{Ni}$, a weaker correlation between the bulk Ni contents and both goethite crystallite size and FWHM of the goethite (110) peak is observed. The stronger 
correlation between bulk $\mathrm{Ni}$ and goethite crystallinity in the upper limonite support our hypothesis that goethite is the main host of Ni.

\subsubsection{Transition zone}

The transition zone is a thin layer $(\sim 6.5 \mathrm{~m})$ between the saprolite and limonite zone and is characterized by an abrupt mineralogical, textural, and geochemical transition from the limonite into the saprolite layer. This layer is comprised of the mineral assemblage goethite+lizardite+chlorite+tremolite+chromite. Goethite is the dominant mineral in the limonite zone whereas lizardite, together with minor amounts of chlorite and tremolite, is characteristic of the saprolite zone. The change in the mineral assemblage in the transition zone is reflected in the geochemistry: abrupt increase in $\mathrm{Mg}$ and $\mathrm{SiO}_{2}$ corresponds to the first appearance of $\mathrm{Mg}$-silicates, decrease in the $\mathrm{Fe}_{2} \mathrm{O}_{3}$ associated with a decrease in abundance of goethite, and the relatively high $\mathrm{Al}_{2} \mathrm{O}_{3}$ due to the presence of tremolite and chlorite. The transition zone has an UMIA of 36, a value in between the expected value of at least 60 for limonite zone and the expected value of 4-8 for the saprolite.

$\mathrm{Ni}$ in the transition zone is hosted predominantly by goethite, but other phases, such as serpentine and chlorite, may also host Ni. Thus, bulk Ni content cannot be used to determine the effect of $\mathrm{Ni}$ content on the structure of goethite in the sample from the transition zone. For both FWHM and crystallite size, the sample from the transition zone is a clear outlier in the generally observed trends.

\subsubsection{Saprolite zone}

The saprolite zone is comprised mostly of serpentine and has a geochemistry dominated by $\mathrm{MgO}$ and $\mathrm{SiO}_{2}$. The upper saprolite $(6.6$ to $6.9 \mathrm{~m})$ is composed of the assemblage lizardite+chlorite+chromite+goethite \pm tremolite. The lower saprolite $(7.5$ to $11 \mathrm{~m})$ contains a significant amount of primary minerals, mostly olivine, and is made up of the mineral assemblage lizardite+olivine+goethite. Except for the topmost sample from the upper saprolite, samples from the saprolite zone have UMIA values between 4 and 7 . Fe is hosted in the saprolite within serpentine, chromite, and poorly crystalline Fe-oxides, occurring as alteration of olivine and serpentine. Minor amounts of $\mathrm{Al}_{2} \mathrm{O}_{3}$ in the saprolite suggest the absence of Al-bearing minerals, although small amounts of Al may substitute for Si in the serpentine crystal structure $[67,68]$. Significant concentrations of Al were observed in saprolite samples containing chlorite.

\subsection{Genetic model of formation of the Sta. Cruz deposit}

The stratification observed in a Ni-laterite profile essentially preserves a "snapshot" of the evolution of laterization where the lowest layers represent the early stages of alteration and the higher layers reflect later more advanced stages [69]. Thus, a complete Ni laterite profile provides information on both the temporal and spatial evolution of the system. Here we present a proposed spatio-temporal model of the formation of the Sta. Cruz nickel laterite deposit, consisting of four stages (Figure 11), incorporating the results of mineralogical-geochemical investigations presented in this study as well as results of an earlier reactive transport modelling of laterization of the outcrop [54].

\subsubsection{Stage 1: early stage alteration}

The earliest stage of alteration of the ZOC involves the serpentinization of the peridotite protolith, forming type 1 serpentine as pseudomorphs after primary minerals (Figure 11, stage 1). Although both olivine and orthopyroxene can be altered to serpentine, olivine is more abundant and has more $\mathrm{Ni}$ content $(0.24$ to $0.36 \mathrm{wt} \%)$ than orthopyroxene $(0.07$ to $0.08 \mathrm{wt} \%)$ in the ZOC peridotite [41]. It follows that olivine is the main source of $\mathrm{Ni}$ in the deposit, thus, the discussions below focus on the serpentinization of olivine. Klein et al. [70] determined that serpentine formed at higher temperatures $\left(200\right.$ to $\left.300^{\circ} \mathrm{C}\right)$, such as near ocean spreading centers, contain abundant magnetite. Type 1 serpentine 
from the least altered rock of the Sta. Cruz deposit are mostly magnetite free (Figure 6), although at relatively higher levels, type 1 serpentine were associated with minor amounts of magnetite. Thus, serpentinization likely occurred at a moderately low temperature (e.g., $\left.<200^{\circ} \mathrm{C}\right)$ in a convergent, subduction-related setting prior to or possibly during the exhumation of the ZOC.

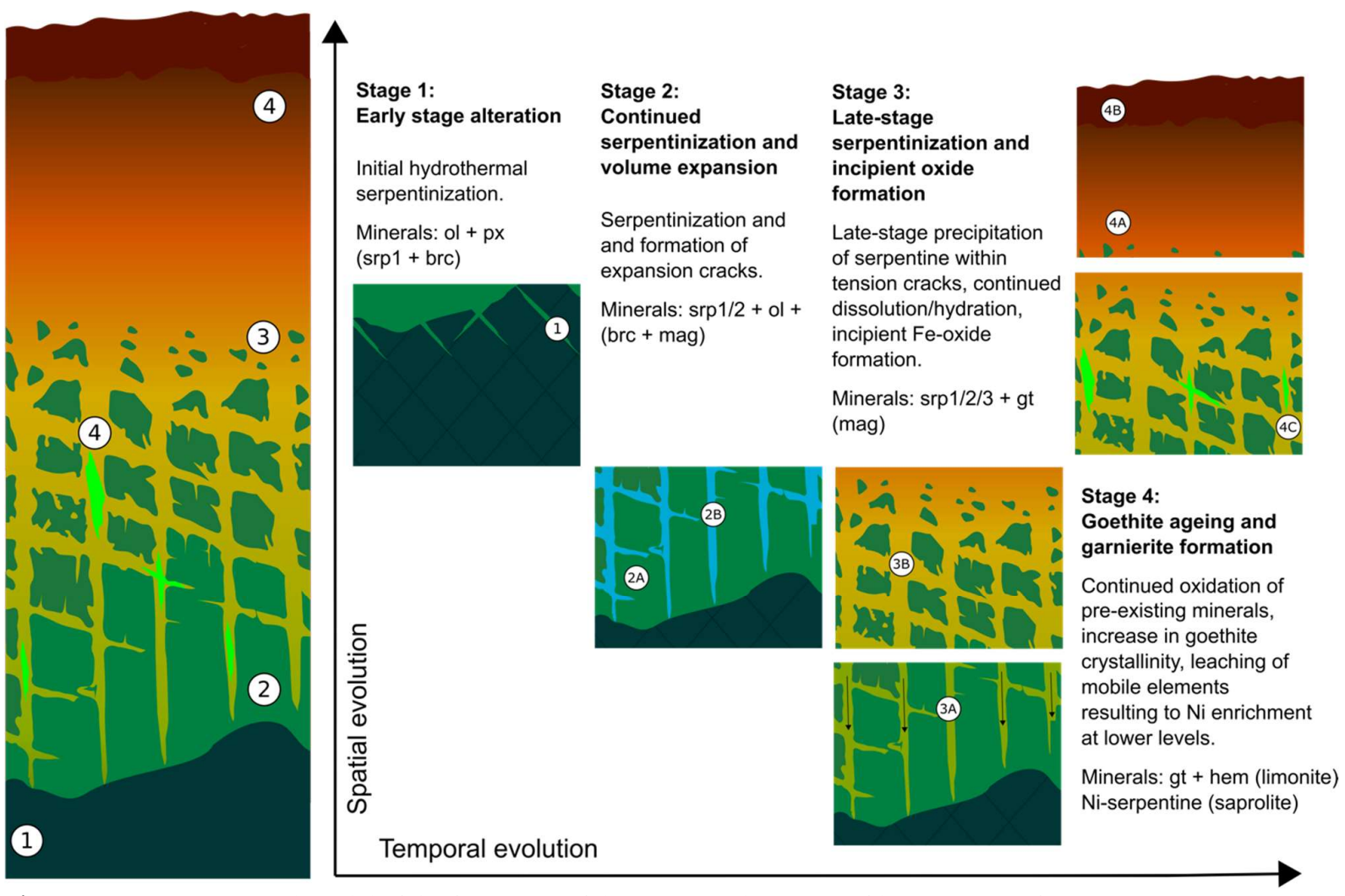

Figure 11. Spatio-temporal model of the formation of the Sta. Cruz laterite profile consisting of 4 stages. During stage 1, initial serpentinization of the protolith before or during the emplacement of the ZOC occurs (1). Stage 2 involves continued serpentinization of the primary minerals (2A). Serpentinization is associated with volume expansion that produces expansion cracks at or near the peridotite-serpentinite boundary (2B). Stage 3 is characterized by the precipitation of serpentine within previously formed expansion cracks (3A). Upwards through the profile, continued alteration and dissolution of primary minerals occur, as well as the incipient oxidation of pre-existing minerals, forming poorly crystalline Fe-oxide. At the last stage, stage 4, further oxidation of pre-existing minerals forms the limonite zone. Goethite, which is initially poorly crystalline, increases in crystallinity as $\mathrm{Ni}$ and other impurities are expelled from its structure (4A). Goethite is also altered to hematite at the topmost part of the profile (4B). Ni and other elements expelled from goethite ageing and hematite formation are leached downwards and contribute to Ni-rich serpentine precipitation in the saprolite zone $(4 \mathrm{C})$. ol $=\mathrm{olivine}, \mathrm{px}$ $=$ pyroxene, $\operatorname{srp}=$ serpentine, brc $=$ brucite, $\operatorname{mag}=$ magnetite, $\mathrm{gt}=$ goethite, hem $=$ hematite .

The early stage serpentinization reaction of olivine and orthopyroxene is generally isochemical [6], consistent with the observed similarity of the ultramafic index of alteration (UMIA) values calculated from the saprolite and bedrock of the Sta. Cruz laterite deposit. Moreover, initial serpentinization, as recorded in the least altered rock (N-1050), typically emanates from grain boundaries and form mesh textures characteristic of type 1 serpentine (Figure 6). These mesh textures are still preserved in more altered samples and are observed around partially or completely dissolved relict olivine (Figure 4-5). During this early stage of alteration, serpentine forms from direct hydration of olivine [71-74]:

$$
\begin{gathered}
(\mathrm{Mg}, \mathrm{Fe}, \mathrm{Ni})_{2} \mathrm{SiO}_{4}+1.5 \mathrm{H}_{2} \mathrm{O} \\
\text { Olivine }
\end{gathered} \underset{\text { Fe-Brucite }}{0.5} \underset{(\mathrm{Mg}, \mathrm{Fe}, \mathrm{Ni})(\mathrm{OH})_{2}}{\rightarrow 0.5} \underset{\left(\mathrm{Mg}, \mathrm{Fe}, \mathrm{Ni}_{3} \mathrm{Si}_{2} \mathrm{O}_{5}(\mathrm{OH})_{4} .\right.}{\text { Serpentine }}
$$


The pseudomorphic nature of type 1 serpentine (i.e., mesh texture) in the least altered rock and in the saprolite samples suggests that early formed type 1 serpentine is formed from direct alteration of olivine $[13,36,66,72,75,76]$ instead of dissolution and reprecipitation upon supersaturation $[8,12,69,77]$. Hydration of olivine is associated with the formation of brucite due to mass balance constraints of Equation 4, even though brucite was not detected in our samples. Positive identification of brucite is known to be difficult, as brucite is oftentimes fine grained in nature and can be present cryptically as interlayers within serpentine [35,78]. In addition, brucite solubility is known to be highly sensitive to $\mathrm{pH}$ [79]. Despite these, brucite is a widely recognized product of serpentinization $[71,74,80,81]$ and has been reported or inferred to occur in other Ni laterite deposits $[33,35,66]$. The Fepartitioning between the alteration phases brucite and serpentine is complex and affected by various factors, including temperature, initial olivine composition, and water-rock ratio, although the Fe content of brucite during serpentinization increases with decreasing temperature [70,73].

The occurrence of minor magnetite together with at least some of the type 1 serpentine may point to a two-step process where an initial serpentinization reaction (Equation 4 ) is followed by the formation of magnetite after brucite, similar to what has been described earlier [35]:

$9(\mathrm{Mg}, \mathrm{Fe}, \mathrm{Ni})(\mathrm{OH})_{2}+4 \mathrm{SiO}_{2} \rightarrow \mathrm{Fe}_{3} \mathrm{O}_{4}+2(\mathrm{Mg}, \mathrm{Fe}, \mathrm{Ni})_{3} \mathrm{Si}_{2} \mathrm{O}_{5}(\mathrm{OH})_{4}+4 \mathrm{H}_{2} \mathrm{O}+\mathrm{H}_{2}$

Fe-Brucite Magnetite Serpentine

\subsubsection{Stage 2: volume expansion and continued serpentinization}

The tilting and uplift that led to the emplacement of the ZOC likely introduced significant fractures and possibly fluid flow pathways into the partially altered peridotite. The reaction of slightly acidic rainwater with the partly altered peridotite results to the dissolution of pre-existing minerals [32]:

$$
\begin{aligned}
& \left(\mathrm{Mg}_{x} \mathrm{Fe}_{y} \mathrm{Ni}_{z}\right)_{2} \mathrm{SiO}_{4}+4 \mathrm{H}+\rightarrow 2 \mathrm{H}_{2} \mathrm{O}+2 x \mathrm{Mg}^{2+}+2 y \mathrm{Fe}^{2+}+2 z \mathrm{Ni}^{2+}+\mathrm{SiO}_{2(\mathrm{aq})} \\
& \quad \text { Olivine } \\
& \left(\mathrm{Mg}_{x} \mathrm{Fe}_{y} \mathrm{Ni}_{z}\right) \mathrm{SiO}_{3}+2 \mathrm{H}+\rightarrow \mathrm{H}_{2} \mathrm{O}+x \mathrm{Mg}^{2+}+y \mathrm{Fe}^{2+}+z \mathrm{Ni}^{2+}+\mathrm{SiO}_{2(\mathrm{aq})} . \\
& \quad \text { Pyroxene }
\end{aligned}
$$

Dissolution features are observed in the primary minerals from samples all throughout the saprolite, with the degree of dissolution increasing upwards through the profile (Figures 3-5). Amorphous Fe-oxides and silica are observed within dissolution cavities after olivine in samples from the upper saprolite at the Sta. Cruz deposit (Figure 4). Interestingly, recent work on the mechanism of mineral dissolution and precipitation [82] highlighted the role of an amorphous material that form directly from the reactant mineral during mineral dissolution.

As more water reacts with the partially serpentinized rock, serpentinization (Equations 4-5) continues, altering the primary minerals (Figure 11, stage 2A). Dissolution reactions (Equations 6-7) also continue providing $\mathrm{SiO}_{2}(\mathrm{aq})$ for Equation 5. Evidence for present-day low temperature serpentinization has been reported as early as 1967 [2,83-85]. Recently, an increasing number of thermodynamic calculations and biogeochemical investigations of rock and water samples in ophiolites and Ni laterite deposits, including the ZOC, suggest that low temperature serpentinization is occurring at ambient conditions [5,30-33,36,66,86-88].

In addition, the unweathered samples from the Zambales ophiolite is known to be only partly serpentinized [41]. Pristine, unweathered peridotite samples has been collected from the ZOC (Figure A1). In the Sta. Cruz deposit, the observed increase in the degree of serpentinization from the least altered rock $(\mathrm{N}-1050)$ to the lower and upper saprolite samples suggests that lower temperature serpentinization has occurred after the exhumation of the ZOC. 
Over time, after olivine is exhausted, serpentine may react with water, producing brucite and $\mathrm{SiO}_{2}(\mathrm{aq})$, following Frost and Beard [74]:

$$
\begin{aligned}
& (\mathrm{Mg}, \mathrm{Fe}, \mathrm{Ni})_{3} \mathrm{Si}_{2} \mathrm{O}_{5}(\mathrm{OH})_{4}+\mathrm{H}_{2} \mathrm{O} \rightarrow 3(\mathrm{Mg}, \mathrm{Fe}, \mathrm{Ni})(\mathrm{OH})_{2}+2 \mathrm{SiO}_{2(\mathrm{aq})} \text {. } \\
& \text { Serpentine Fe-Brucite }
\end{aligned}
$$

At these low temperatures, the Fe content of brucite is expected to be relatively high $[73,89]$. The occurrence of Fe-Mg hydroxides and silica are observed in the samples collected from the upper saprolite which have little to no primary olivine remaining (Figure $4 \mathrm{c}-\mathrm{f})$. In addition, the occurrence of dark brown discoloration on some of the type 1 serpentine (Figure 5a) hints to direct alteration of serpentine to Fe-Mg (oxy)hydroxides (Equation 8).

One major consequence of the hydration of peridotite is the associated volume increase that occurs as a rock, composed of dense minerals, is altered to less dense, secondary minerals [76,90,91]. Serpentinization is a generally constant-composition process [6], and the decrease in the density of the reaction products will result in an increase in the overall volume of the system. Volume expansion associated with serpentinization has been discussed earlier by O'Hanley [91]. More recently, Klein and Le Roux [90] experimentally measured a volume increase of $44 \pm 8 \%$ associated with serpentinization for a duration of 10 to 18 months. The associated volume expansion can both seal existing fractures in the system and induce new fractures at the same time (Figure 11, stage 2B). At or near the reaction site, the crystallization of higher volume serpentine can seal existing fractures. However, away from serpentine-olivine reaction sites, the force of crystallization and volume expansion will induce secondary tension cracks [76,91], adding fluid flow pathways to the system and promoting further reaction with water. These tension cracks or cross fractures which were described by O'Hanley [91] can be later filled by serpentine minerals. These are observed in the saprolite zone of the Sta. Cruz laterite profile in the form of roughly parallel type 2 serpentine veins (e.g., N-900, Figure 5). The cracks are formed during continued serpentinization and are later filled by late-stage serpentine, likely formed from fluids leached from the upper horizons [11,12,19].

In addition to serpentine and brucite, abundant magnetite is observed, together with type 3 serpentine in samples near the limonite-saprolite boundary (e.g., N-650R, Figure 4). Magnetite is also detected but in minor amounts together with both mesh-type and vein-type serpentine from other depths. As suggested earlier [74], at low silica concentrations, magnetite can form from the oxidation of Fe-rich serpentine via:

$$
\begin{gathered}
\mathrm{Fe}_{3} \mathrm{Si}_{2} \mathrm{O}_{5}(\mathrm{OH})_{4} \\
\text { Serpentine }
\end{gathered}+0.5 \mathrm{O}_{2(\mathrm{aq})} \rightarrow \mathrm{Fe}_{3} \mathrm{O}_{4}+2 \mathrm{SiO}_{2(\mathrm{aq})}+2 \mathrm{H}_{2} \mathrm{O} .
$$

Magnetite is also predicted to form directly from the hydration of olivine; however, this occurs at relatively high temperatures between 250 to $330^{\circ} \mathrm{C}$ depending on the protolith and water-rock ratios [70,89]. Since we only observe these abundant magnetite in the upper levels of the profile, and not in the least altered rocks nor in the lower saprolite rocks, we hypothesize that for the Sta. Cruz laterite deposit, very low silica activities drive the oxidation of Fe-serpentine to magnetite. Therefore, type 3 magnetite-rich veins are likely formed from the alteration of earlier formed serpentines.

\subsubsection{Stage 3: late stage serpentinization, dissolution, and incipient oxide formation}

Volume expansion from the earlier stages of laterite formation results in secondary tension cracks away from the peridotite-serpentine reaction front $[76,90,91]$. These cracks introduce secondary fluid pathways to the system and may be filled by late-stage type 2 serpentine veins [91] (Figure 11, stage 3A). Roughly parallel late-stage serpentine veins are observed in the samples adjacent to the least altered rock in the studied profile (e.g., N-900, Figure 5). The serpentine veins are likely formed from solutions leached $[11,12,19]$ from the upper horizons of the profile following the reaction [32]:

$2 x \mathrm{Mg}^{2+}+2 z \mathrm{Ni}^{2+}+3.33 \mathrm{H}_{2} \mathrm{O}+1.33 \mathrm{SiO}_{2(\mathrm{aq})} \rightarrow 0.67\left(\mathrm{Mg}_{x} \mathrm{Ni}_{z}\right)_{3} \mathrm{Si}_{2} \mathrm{O}_{5}(\mathrm{OH})_{4}$ 
Further reaction with oxidized rainwater can result in the continued dissolution of preexisting minerals in the system (Equations 6-7). $\mathrm{Mg}$ and $\mathrm{Si}$ are leached towards the lower levels while Fe can be oxidized to form poorly crystalline goethite (Figure 11, stage 3B) $[12,32,69,77]$ :

$$
\begin{array}{ll}
4 \mathrm{Fe}^{2+}+\mathrm{O}_{2}+\mathrm{H}_{2} \mathrm{O} \rightarrow & 4 \mathrm{FeO}(\mathrm{OH})+8 \mathrm{H}^{+} \\
\text {Goethite }
\end{array}
$$

Towards the end of this stage, continued dissolution of serpentine and any pre-existing silicates occurs, resulting in an oxide horizon composed dominantly of goethite. The poor crystallinity of goethite precursor is supported by the absence of well-defined peaks in the diffractogram of the saprolite samples from the Sta. Cruz deposit [52]. Petrographic investigation of saprolite samples revealed that secondary magnetite is altered to hematite, especially at higher depths (e.g., N-650, N-660; Figure 4). In the presence of oxygen, magnetite can be altered to maghemite and then to hematite [65], according to the following reaction:

$$
\begin{array}{cc}
\mathrm{Fe}_{3} \mathrm{O}_{4} & +0.25 \mathrm{O}_{2} \rightarrow 1.5 \mathrm{Fe}_{2} \mathrm{O}_{3} . \\
\text { Magnetite } & \text { Maghemite/Hematite }
\end{array}
$$

\subsubsection{Stage 4: goethite ageing and Ni-rich serpentine formation}

The last stage in the formation of the laterite profile involves goethite ageing [37] and the expansion of the limonite zone, accompanied by the formation of later stage Ni-rich serpentine veins at the lower levels (Figure 11, stage 4A,4B). At this stage, most of the silicates formed from the first two stages have already been dissolved or altered to goethite (Equations 6-7,11). Goethite initially has low crystallinity [37,69,77], which is attributed to the incorporation of elements, including $\mathrm{Ni}$, that introduce structural defects in the goethite crystal structure [37]. At this stage of laterization, $\mathrm{Ni}$ and other impurities are expelled from the structure of goethite, and subsequently leach away towards the lower horizons $[14,37,77]$. The expulsion of $\mathrm{Ni}$ from goethite results in goethite ageing or the upward increase in the crystallinity of goethite within the limonite zone as laterization progresses [37-39]. In the Sta. Cruz deposit, goethite ageing is supported by the observed correlation between the bulk Ni content in the limonite and FWHM of the goethite (110) peak. Higher up in the profile, hematite may form from the dehydroxylation of goethite according to [65]:

$$
\begin{array}{lr}
\mathrm{FeO}(\mathrm{OH}) & \rightarrow 0.5 \mathrm{H}_{2} \mathrm{O}+0.5 \mathrm{Fe}_{2} \mathrm{O}_{3} . \\
\text { Goethite } & \text { Hematite }
\end{array}
$$

The prevalent silicate dissolution, expulsion of $\mathrm{Ni}$ from goethite due to goethite ageing, as well as the transformation of goethite to hematite (Equation 13), result in the loss of mobile elements, including $\mathrm{Mg}$, $\mathrm{Si}$, and $\mathrm{Ni}$. These elements are leached towards lower horizons, where they form Ni bearing silicates, mostly Ni-bearing serpentine [77], which are observed in the Sta. Cruz deposit, or talc-like phases called garnierites in other deposits $[17,19,20,33,35,66]$. The degree and depth of leaching of mobile elements are controlled by the depth of the water table. Above the water table, leaching of mobile elements occurs, while below the water table these mobile elements accumulate and become enriched $[13,77]$. Elements leached from the upper horizons can also alter the pre-existing secondary minerals in the lower horizon, as described in the reaction below [12,33]:

$$
\underset{\text { Serpentine }}{\mathrm{Mg}_{3} \mathrm{Si}_{2} \mathrm{O}_{5}(\mathrm{OH})_{4}+z \mathrm{Ni}^{2+}} \rightarrow \underset{\mathrm{Ni}}{\left(\mathrm{Mg}_{1-2} \mathrm{Ni}_{2}\right)_{3} \mathrm{Si}_{2} \mathrm{O}_{5}(\mathrm{OH})_{4} .}
$$

Direct alteration of serpentine to Ni-rich serpentine is observed in the saprolite samples (N-650V, N-1100, Figure 3) in serpentine precipitated along secondary cracks. In addition, 
this upper Ni-serpentine vein which is observed cross cutting the upper saprolite zone is associated with the highest $\mathrm{Ni}$ content and highest $\mathrm{Ni}$ mass gain in the profile.

Over time, the limonite zone expands as oxide-forming reactions (Equations 11-13) continue to progress, deepening the limonite-saprolite zone boundary and increasing the thickness of the limonite zone. The expansion of the limonite zone is affected by a number of factors, including time, the rate of erosion, relief, and climate. A moderate to low-lying relief in a tropical climate provides the ideal conditions for laterite formation. Low to moderate relief results in a limited erosion rate, allowing the preservation of the newly formed limonite zone, and at the same time providing a low-lying water table. Since leaching occurs above the water table, a deep water table allows leaching of a thicker layer of rock and consequently an enhanced supergene $\mathrm{Ni}$ enrichment below the water table $[8,13]$.

\section{Conclusions}

Combined mineralogical-geochemical analysis revealed that the Sta. Cruz nickel laterite deposit is composed of two main zones, the limonite and saprolite zones, separated by a thin transition zone. Structural investigation of goethite within the limonite zone resulted in a negative correlation between the bulk nickel content and crystallinity of goethite, and between bulk nickel content and crystallite size, emphasizing the important role that goethite plays during the formation of the limonite zone. We present a spatio-temporal model of the formation of the Sta. Cruz laterite composed of four stages. The first two stages include a series of serpentinization reactions that occurred before and after exhumation of the ZOC, followed by serpentinization related volume expansion. Dissolution of primary minerals resulted to the precipitation of Ni-rich serpentine into previously formed tension cracks in the lower levels while residual enrichment of Fe formed the goethite-dominated limonite zone. The model involves a series of reactions that link serpentinization with oxidation reactions and highlights the key roles of serpentine, Februcite, and goethite in the formation of the nickel laterite profile. Our work supports a growing body of literature suggesting that serpentinization at ambient temperature is possible and that serpentinization associated with weathering might be more significant than previously realized.

Author Contributions: K.A. conceptualized the study, collected the samples, performed the analyses, and wrote the first draft of the manuscript. C.A. and C.S. supervised the study. C.A. provided resources to conduct the study. C.A., C.S., and C.T. reviewed, revised, and edited the manuscript. All authors have read and agreed to the published version of the manuscript.

Funding: This research received funding from the University of the Philippines - Office of the Vice Chancellor for Research and Development -Thesis and Dissertation Grant and the University of the Philippines - National Institute of Geological Sciences Research Grant to K.A.

Data Availability Statement: Data are contained within the article or in the appendix.

Acknowledgments: Arnulfo Santiago is thanked for welcoming and allowing us to collect the samples used in this study. We also thank Gerald Quiña and Jumar Valdez for their assistance during the fieldwork. James Cesar Refran and James Jimenez are thanked for helping with the photography of the hand samples and thin sections. We also thank the student assistants of the Earth Materials Science laboratories for their assistance in the sample preparation. James Cabreros and Timothy Iringan are acknowledged for their help with some of the figures. We thank the academic editors Cristina Domènech and Cristina Villanova-de-Benavent and three anonymous reviewers for constructive comments that greatly improved the manuscript.

Conflicts of Interest: The authors declare no conflict of interest. 


\section{Appendix A}

Table A1. Calculated relative mass changes of the samples from the Sta. Cruz laterite.

\begin{tabular}{|c|c|c|c|c|c|c|c|c|c|c|}
\hline Sam- & Horizon $^{1}$ & Depth (m) & $\mathrm{SiO}_{2}$ & $\mathrm{Al}_{2} \mathrm{O}_{3}$ & $\mathrm{Cr}_{2} \mathrm{O}_{3}$ & $\mathrm{MnO}$ & $\mathrm{NiO}$ & $\mathrm{MgO}$ & Co & LOI \\
\hline $\mathrm{N}-000$ & UL & 0 & -99 & -33 & 159 & 21 & -53 & -99 & 85 & -85 \\
\hline $\mathrm{N}-040$ & UL & 0.4 & -98 & -19 & 4 & -5 & -58 & -100 & 42 & -82 \\
\hline $\mathrm{N}-080$ & UL & 0.8 & -97 & 1 & 14 & -1 & -57 & -100 & 36 & -81 \\
\hline $\mathrm{N}-120$ & UL & 1.2 & -97 & 6 & 20 & 15 & -54 & -100 & 35 & -80 \\
\hline $\mathrm{N}-160$ & UL & 1.6 & -97 & -7 & 15 & 3 & -55 & -100 & 28 & -82 \\
\hline $\mathrm{N}-200$ & UL & 2 & -97 & -14 & 13 & 0 & -56 & -100 & 25 & -82 \\
\hline $\mathrm{N}-240$ & UL & 2.4 & -98 & -29 & 3 & 6 & -56 & -100 & 40 & -83 \\
\hline $\mathrm{N}-280$ & LL & 2.8 & -99 & -62 & 29 & 12 & -52 & -100 & 20 & -85 \\
\hline $\mathrm{N}-320$ & LL & 3.2 & -99 & -65 & 52 & 12 & -51 & -100 & 38 & -87 \\
\hline $\mathrm{N}-360$ & LL & 3.6 & -99 & -70 & 67 & 8 & -53 & -99 & 17 & -87 \\
\hline $\mathrm{N}-400$ & LL & 4 & -99 & -66 & 47 & 9 & -51 & -99 & 17 & -86 \\
\hline $\mathrm{N}-440$ & LL & 4.4 & -99 & -63 & 1 & 17 & -50 & -99 & 33 & -86 \\
\hline $\mathrm{N}-480$ & LL & 4.8 & -99 & -82 & -32 & 17 & -52 & -100 & -32 & -86 \\
\hline $\mathrm{N}-520$ & LL & 5.2 & -99 & -74 & 51 & 24 & -56 & -99 & 24 & -86 \\
\hline $\mathrm{N}-560$ & LL & 5.6 & -99 & -70 & 69 & 15 & -49 & -99 & 118 & -85 \\
\hline N-600 & LL & 6 & -99 & -69 & 73 & 6 & -47 & -99 & 109 & -85 \\
\hline N-640 & $\mathrm{T}$ & 6.4 & -92 & -40 & 194 & 24 & 27 & -94 & 183 & -78 \\
\hline $\mathrm{N}-650$ & V & 6.5 & -24 & -88 & 23 & -7 & 727 & -36 & 38 & 16 \\
\hline $\mathrm{N}-690$ & US & 6.9 & -36 & 26 & 1198 & 22 & 161 & -37 & 26 & -3 \\
\hline N-750 & LS & 7.5 & -20 & -88 & 16 & 4 & 301 & -26 & 42 & 5 \\
\hline N-900 & LS & 9 & -38 & -86 & 49 & 10 & 410 & -45 & 46 & -14 \\
\hline N-1050 & LS & 10.5 & -42 & 3 & 990 & 36 & 389 & -46 & 29 & -20 \\
\hline $\mathrm{N}-1100$ & V & 11 & -26 & -90 & 1 & 4 & 539 & -34 & 15 & -4 \\
\hline
\end{tabular}




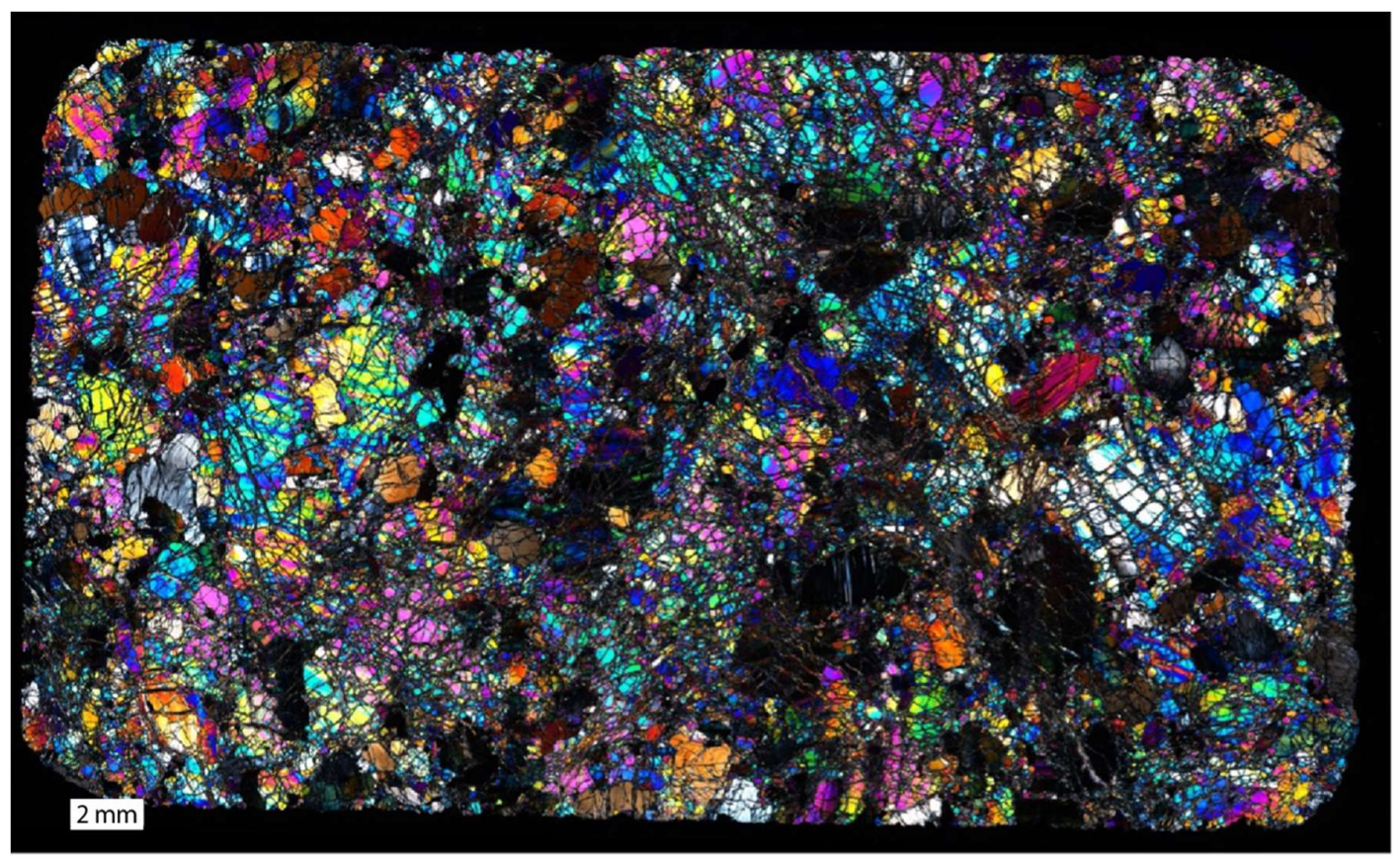

Figure A1. Thin section mosaic of a peridotite sample from the Zambales ophiolite in crossed-polarized light. Sample collected by K. Aquino (unpublished data).

\section{References}

1. Jöns, N.; Bach, W. Encyclopedia of Marine Geosciences; Harff, J., Meschede, M., Petersen, S., Thiede, Jö., Eds.; Encyclopedia of Earth Sciences Series; Springer Netherlands: Dordrecht, 2016; Vol. 20; ISBN 978-94-007-6237-4.

2. Neal, C.; Stanger, G. Past and present serpentinisation of ultramafic rocks: an example from the Semail Ophiolite nappe of northern Oman. Chem. Weather. 1985, 249-247.

3. Kelley, D.S.; Karson, J.A.; Blackman, D.K.; Früh-Green, G.L.; Butterfield, D.A.; Lilley, M.D.; Olson, E.J.; Schrenk, M.O.; Roe, K.K.; Lebon, G.T.; et al. An off-axis hydrothermal vent field near the mid-atlantic ridge at $30^{\circ}$ n. Nature 2001, 412, 145-149, doi:10.1038/35084000.

4. Charlou, J.L.; Donval, J.P.; Fouquet, Y.; Jean-Baptiste, P.; Holm, N. Geochemistry of high H2 and CH4 vent fluids issuing from ultramafic rocks at the Rainbow hydrothermal field (36²14'N,MAR). Chem. Geol. 2002, 191, 345-359, doi:10.1016/S00092541(02)00134-1.

5. Abrajano, T.A.; Sturchio, N.C.; Kennedy, B.M.; Lyon, G.L.; Muehlenbachs, K.; Bohlke, J.K. Geochemistry of reduced gas related to serpentinization of the Zambales ophiolite, Philippines. Appl. Geochemistry 1990, 5, 625-630, doi:10.1016/08832927(90)90060-I.

6. Deschamps, F.; Godard, M.; Guillot, S.; Hattori, K. Lithos Geochemistry of subduction zone serpentinites : A review. LITHOS 2013, 178, 96-127, doi:10.1016/j.lithos.2013.05.019.

7. Ohara, Y.; Reagan, M.K.; Fujikura, K.; Watanabe, H.; Michibayashi, K.; Ishii, T.; Stern, R.J.; Pujana, I.; Martinez, F.; Girard, G.; et al. A serpentinite-hosted ecosystem in the Southern Mariana Forearc. Proc. Natl. Acad. Sci. U. S. A. 2012, 109, 28312835, doi:10.1073/pnas.1112005109.

8. Golightly, J. Nickeliferous laterite deposits. Econ. Geol. 1981, 75th Anniv, 710-735.

9. Brand, N.W.; Butt, C.R.M.; Elias, M. Nickel Laterites: Classification and Features. J. Aust. Geol. Geophys. 1998, 17, 81-88.

10. Elias, M. Nickel laterite deposits - geological overview , resources and exploitation. Giant Ore Depos. Charact. Genes. Explor. CODES Spec. Publ. 4, Hobart, Univ. Tasmania 2002, 4, 205-220.

11. Gleeson, S.A.; Butt, C.R.M.; Elias, M. SEG Newsletter. 2003, pp. 1, 12-18.

12. Butt, C.R.M.; Cluzel, D. Nickel laterite ore deposits: Weathered serpentinites. Elements 2013, 9, 123-128, doi:10.2113/gselements.9.2.123.

13. Golightly, J.P. Progress in understanding the evolution of nickel laterites. Goldfarb, R.J., Marsh, E. E., Monecke, T., eds., Chall. Find. new Miner. Resour. Metallog. Innov. Explor. new Discov. Soc. Econ. Geol. Spec. Publ. 2010, 15, 451-485.

14. Trescases, J.-J. Weathering and geochemical behaviour of the elements of ultramafic rocks in New Caledonia. Bur. Miner. Resour. Geol. Geophys. Canberra 1973, 141, 149-161. 
15. Pecora, W.T. Nickel-silicate and associated nickel-cobalt-manganese-oxide deposits near Sao Jose do Tocantins, Goiaz, Brazil. US Geol. Surv. Bull. 1944, 935-E, 247-305.

16. Faust, G. The hydrous nickel-magnesium silicates -- the garnierite group. Am. Mineral. 1966, 51, 279.

17. Brindley, G.W.; Hang, P.T.H.I. The Nature of Garnierites - I Structures, Chemical Compositions and Color Characteristics. Clays Clay Miner. 1973, 21, 27-40.

18. Gali, S.; Soler, J.M.; Proenza, J.A.; Lewis, J.F.; Cama, J.; Tauler, E. Ni enrichment and stability of Al-free garnierite solidsolutions: A thermodynamic approach. Clays Clay Miner. 2012, 60, 121-135, doi:10.1346/CCMN.2012.0600203.

19. Villanova-de-Benavent, C.; Proenza, J.A.; Galí, S.; García-Casco, A.; Tauler, E.; Lewis, J.F.; Longo, F. Garnierites and garnierites: Textures, mineralogy and geochemistry of garnierites in the Falcondo Ni-laterite deposit, Dominican Republic. Ore Geol. Rev. 2014, 58, 91-109, doi:10.1016/j.oregeorev.2013.10.008.

20. Brindley, G.W. The Nature and Nomenclature of Hydrous Nickel-Containing Silicates. Clay Miner. 1974, 10, 271-277, doi:10.1180/claymin.1974.010.4.05.

21. Kelley, D.S.; Karson, J.A.; Früh-Green, G.L.; Yoerger, D.R.; Shank, T.M.; Butterfield, D.A.; Hayes, J.M.; Schrenk, M.O.; Olson, E.J.; Proskurowski, G.; et al. A serpentinite-hosted ecosystem: The Lost City hydrothermal field. Science (80-. ). 2005, 307, 1428-1434, doi:10.1126/science.1102556.

22. Schmidt, K.; Koschinsky, A.; Garbe-Schönberg, D.; de Carvalho, L.M.; Seifert, R. Geochemistry of hydrothermal fluids from the ultramafic-hosted Logatchev hydrothermal field, $15^{\circ} \mathrm{N}$ on the Mid-Atlantic Ridge: Temporal and spatial investigation. Chem. Geol. 2007, 242, 1-21, doi:10.1016/j.chemgeo.2007.01.023.

23. Lang, S.Q.; Butterfield, D.A.; Schulte, M.; Kelley, D.S.; Lilley, M.D. Elevated concentrations of formate, acetate and dissolved organic carbon found at the Lost City hydrothermal field. Geochim. Cosmochim. Acta 2010, 74, 941-952, doi:10.1016/j.gca.2009.10.045.

24. Monnin, C.; Chavagnac, V.; Boulart, C.; Ménez, B.; Gérard, M.; Gérard, E.; Pisapia, C.; Quéméneur, M.; Erauso, G.; Postec, A.; et al. Fluid chemistry of the low temperature hyperalkaline hydrothermal system of Prony bay (New Caledonia). Biogeosciences 2014, 11, 5687-5706, doi:10.5194/bg-11-5687-2014.

25. Eickenbusch, P.; Takai, K.; Sissman, O.; Suzuki, S.; Menzies, C.; Sakai, S.; Sansjofre, P.; Tasumi, E.; Bernasconi, S.M.; Glombitza, C.; et al. Origin of short-chain organic acids in serpentinite mud volcanoes of the Mariana convergent margin. Front. Microbiol. 2019, 10, 1-21, doi:10.3389/fmicb.2019.01729.

26. McCollom, T.M. Geochemical Constraints on Sources of Metabolic Energy for Chemolithoautotrophy in Ultramafic-Hosted Deep-Sea Hydrothermal Systems. Astrobiology 2007, 7, 933-950, doi:10.1089/ast.2006.0119.

27. Sleep, N.H. The Hadean-Archaean environment. Cold Spring Harb. Perspect. Biol. 2010, 2, 1-14, doi:10.1101/cshperspect.a002527.

28. Martin, W.; Russell, M.J. On the origin of biochemistry at an alkaline hydrothermal vent. Philos. Trans. R. Soc. B Biol. Sci. 2007, 362, 1887-1925, doi:10.1098/rstb.2006.1881.

29. Schulte, M.; Blake, D.; Hoehler, T.; McCollom, T. Serpentinization and It's Implication for Life on Early Earth and Mars. Astrobiology 2006, 6, 364-376.

30. de Obeso, J.C.; Kelemen, P.B. Major element mobility during serpentinization, oxidation and weathering of mantle peridotite at low temperatures. Philos. Trans. A. Math. Phys. Eng. Sci. 2020, 378, 20180433, doi:10.1098/rsta.2018.0433.

31. Templeton, A.S.; Ellison, E.T.; Glombitza, C.; Morono, Y.; Rempfert, K.R.; Hoehler, T.M.; Zeigler, S.D.; Kraus, E.A.; Spear, J.R.; Nothaft, D.B.; et al. Accessing the Subsurface Biosphere Within Rocks Undergoing Active Low-Temperature Serpentinization in the Samail Ophiolite (Oman Drilling Project). J. Geophys. Res. Biogeosciences 2021, 126, 1-30, doi:10.1029/2021jg006315.

32. Leong, J.A.M.; Shock, E.L. Thermodynamic constraints on the geochemistry of low-temperature, continental, serpentinization-generated fluids. Am. J. Sci. 2020, 320, 185-235, doi:10.2475/03.2020.01.

33. Villanova-de-Benavent, C.; Domènech, C.; Tauler, E.; Galí, S.; Tassara, S.; Proenza, J.A. Fe-Ni-bearing serpentines from the saprolite horizon of Caribbean Ni-laterite deposits: new insights from thermodynamic calculations. Miner. Depos. 2017, 52, 979-992, doi:10.1007/s00126-016-0683-7.

34. Ulrich, M.; Muñoz, M.; Boulvais, P.; Cathelineau, M.; Cluzel, D.; Guillot, S.; Picard, C. Serpentinization of New Caledonia peridotites: from depth to (sub-)surface. Contrib. to Mineral. Petrol. 2020, 175, 1-25, doi:10.1007/s00410-020-01713-0.

35. Tupaz, C.A.J.; Watanabe, Y.; Sanematsu, K.; Echigo, T. Mineralogy and geochemistry of the Berong Ni-Co laterite deposit, Palawan, Philippines. Ore Geol. Rev. 2020, 125, 103686, doi:10.1016/j.oregeorev.2020.103686.

36. Muñoz, M.; Ulrich, M.; Cathelineau, M.; Mathon, O. Weathering processes and crystal chemistry of Ni-bearing minerals in saprock horizons of New Caledonia ophiolite. J. Geochemical Explor. 2019, 198, 82-99, doi:10.1016/j.gexplo.2018.12.007.

37. Dublet, G.; Juillot, F.; Morin, G.; Fritsch, E.; Fandeur, D.; Brown, G.E. Goethite aging explains Ni depletion in upper units of ultramafic lateritic ores from New Caledonia. Geochim. Cosmochim. Acta 2015, 160, 1-15, doi:10.1016/j.gca.2015.03.015.

38. Kuhnel, R.A.; Roorda, H.J.; Steensma, J.J.; Kühnel, R.A.; Roorda, H.J.; Steensma, J.J.; Kuhnel, R.A.; Roorda, H.J.; Steensma, J.J.; Kühnel, R.A.; et al. The crystallinity of minerals-A new variable in pedogenetic processes: A study of goethite and associated silicates in laterites. Clays Clay Miner. 1975, 23, 349-354, doi:10.1346/CCMN.1975.0230503.

39. Trescases, J.-J. L'évolution géochimique supergène des roches ultrabasiques en zone tropicale et la formation des gisements nickéliferes de Nouvelle-Calédonie; 1975; Vol. 78; ISBN 2709903628.

40. Abrajano, T.A.; Pasteris, J.D.; Bacuta, G.C. Zambales ophiolite, Philippines I. Geology and petrology of the critical zone of 
the Acoje massif. Tectonophysics 1989, 168, 65-100, doi:10.1016/0040-1951(89)90369-7.

41. Hawkins, J.W.; Evans, C. a Geology of the Zambales Range, Luzon, Philippine Islands - ophiolite derived from an island arc-backarc basin pair. Tecton. Geol. Evol. Southeast Asian seas islands, Part 2 (Hayes, D.E., Ed.) Am. Geophys. Union, Geophys. Monogr. Ser. 1983, 27, 95-123.

42. Rossman, D.L.; Castañada, G.C.; Bacuta, G.C. Geology of the Zambales ophiolite, Luzon, Philippines. Tectonophysics 1989, 168, doi:10.1016/0040-1951(89)90366-1.

43. Yumul, G.P.; Dimalanta, C.B. Geology of the Southern Zambales Ophiolite Complex, (Philippines): Juxtaposed terranes of diverse origin. J. Asian Earth Sci. 1997, 15, 413-421, doi:10.1016/S0743-9547(97)00019-6.

44. Bacuta, G.C. Geology of some Alpine-type chromite deposits in the Philippines.pdf. J. Geol. Soc. Philipp. 1979, 33, 44-80.

45. Yumul, G.P.; Dimalanta, C.B.; Faustino, D. V.; De Jesus, J. V. Translation and docking of an arc terrane: geological and geochemical evidence from the southern Zambales ophiolite complex, Philippines. Tectonophysics 1998, 293, 255-272, doi:10.1016/S0040-1951(98)00096-1.

46. Garrison, R.E.; Espiritu, E.; Horan, L.J.; Mack, L.E. Petrology, sedimentology, and diagenesis of hemipelagic limestone and tuffaceous turbidites in the Aksitero Formation, central Luzon, Philippines. U. S. Geol. Surv. Prof. Pap. 1979, 1112, 15-16, doi:-.

47. Amato, F.L. Stratigraphic paleontology in the Philippines. Philipp. Geol. 1965, 19, 1-24.

48. Fuller, M.; Haston, R.; Almasco, J. Paleomagnetism of the Zambales ophiolite, Luzon, northern Philippines. Tectonophysics 1989, 168, 171-203, doi:10.1016/0040-1951(89)90375-2.

49. Encarnación, J.P.; Mukasa, S.B.; Obille, E.C. Zircon U-Pb geochronology of the Zambales and Angat Ophiolites, Luzon, Philippines: Evidence for an Eocene arc-back arc pair. J. Geophys. Res. 1993, 98, 19991, doi:10.1029/93JB02167.

50. Schweller, W.J.; Karig, D.E.; Bachman, S.B. Original Setting and Emplacement History of the Zambales Ophiolite, Luzon, Phillipines, from Stratigraphic Evidence. Tecton. Geol. Evol. Southeast Asian Seas Islands Part 2 1983, 27, 124-138, doi:10.1029/GM027p0124.

51. Taylor, B.; Hayes, D.E. The tectonic evolution of the South China Basin. Tecton. Geol. Evol. Southeast Asian seas islands 1980, 23, 89-104.

52. Aquino, K.A.; Arcilla, C.A.; Schardt, C.S. Mineralogical Zonation of the Sta. Cruz Nickel Laterite Deposit, Zambales, Philippines Obtained from Detailed X-Ray Diffraction Coupled with Rietveld Refinement. J. Geol. Soc. Philipp. 2019, 73, 114.

53. Santiago, A.P. de B. Evaluation of Ni-bearing saprolite resources contained in Filipinas Mining Corporation MPSA No. 2682008-III located Barangay Guinabon, Sta. Cruz, Zambales, Philippines. 2015.

54. Aquino, K.A. Spatio-temporal evolution of laterization: Insights from detailed mineralogical characterization and reactive transport modelling of Sta. Cruz nickel laterite deposit, Zambales, Philippines, University of the Philippines, 2018.

55. Nickel, E.H.; Nichols, M.C. Mineral database 2003.

56. Cullity, B.D.; Stock, S.R. Elements of X-Ray Diffraction. In; Prentice Hall, Englewood Cliffs, NJ, $2001 ;$ p. 664.

57. Grant, J.A. Isocon analysis : A brief review of the method and applications. 2005, 30, 997-1004, doi:10.1016/j.pce.2004.11.003.

58. Grant, J.A. The isocon diagram-a simple solution to Gresens' equation for metasomatic alteration. Econ. Geol. 1986, 81, 19761982, doi:10.2113/gsecongeo.81.8.1976.

59. Quesnel, B.; de Veslud, C.L.C.; Boulvais, P.; Gautier, P.; Cathelineau, M.; Drouillet, M. 3D modeling of the laterites on top of the Koniambo Massif, New Caledonia: refinement of the per descensum lateritic model for nickel mineralization. Miner. Depos. 2017, 52, 961-978, doi:10.1007/s00126-017-0712-1.

60. Aiglsperger, T.; Proenza, J.A.; Lewis, J.F.; Labrador, M.; Svojtka, M.; Rojas-Purón, A.; Longo, F.; Ďurišová, J. Critical metals (REE, Sc, PGE) in Ni laterites from Cuba and the Dominican Republic. Ore Geol. Rev. 2016, 73, 127-147, doi:10.1016/j.oregeorev.2015.10.010.

61. Babechuk, M.G.; Widdowson, M.; Kamber, B.S. Quantifying chemical weathering intensity and trace element release from two contrasting basalt profiles, Deccan Traps, India. Chem. Geol. 2014, 363, 56-75, doi:10.1016/j.chemgeo.2013.10.027.

62. Parker, A. An Index of Weathering for Silicate Rocks. Geol. Mag. 1970, 107, 501-504, doi:10.1017/S0016756800058581.

63. Ohta, T.; Arai, H. Statistical empirical index of chemical weathering in igneous rocks: A new tool for evaluating the degree of weathering. Chem. Geol. 2007, 240, 280-297, doi:10.1016/j.chemgeo.2007.02.017.

64. Tupaz, C.A.J.; Watanabe, Y.; Sanematsu, K.; Echigo, T. Spectral and chemical studies of iron and manganese oxyhydroxides in laterite developed on ultramafic rocks. Resour. Geol. 2021, 71, 377-391, doi:10.1111/rge.12272.

65. Cornell, R.M.; Schwertmann, U. The Iron Oxides: Structure: Properties, reactions, Occurences and Uses; Wiley-VCH, 2003; ISBN 3527302743.

66. Tupaz, C.A.J.; Watanabe, Y.; Sanematsu, K.; Echigo, T.; Arcilla, C.; Ferrer, C. Ni-co mineralization in the intex laterite deposit, Mindoro, Philippines. Minerals 2020, 10, 1-33, doi:10.3390/min10070579.

67. Evans, B.W.; Hattori, K.; Baronnet, A. Serpentinite: What, Why, Where? Elements 2013, 9, 99-106, doi:10.2113/gselements.9.2.99.

68. Rinaudo, C.A.; Gastaldi, D.A. Characterization of Chrysotile, Antigorite, and Lizardite by FT-Raman Spectroscopy. 2003, 41, 883-890.

69. Elias, M. Nickel laterite deposits - geological overview, resources and exploitation. Giant Ore Depos. Charact. Genes. Explor. CODES Spec. Publ. 4, 2002, 4, 205-220.

70. Klein, F.; Bach, W.; Humphris, S.E.; Kahl, W.A.; Jöns, N.; Moskowitz, B.; Berquó, T.S. Magnetite in seafloor serpentinite- 
Some like it hot. Geology 2014, 42, 135-138, doi:10.1130/G35068.1.

71. Beard, J.S.; Frost, B.R.; Fryer, P.; McCaig, A.; Searle, R.; Ildefonse, B.; Zinin, P.; Sharma, S.K. Onset and progression of serpentinization and magnetite formation in Olivine-rich troctolite from IODP hole U1309D. J. Petrol. 2009, 50, 387-403, doi:10.1093/petrology/egp004.

72. Frost, B.R.; Evans, K.A.; Swapp, S.M.; Beard, J.S.; Mothersole, F.E. The process of serpentinization in dunite from New Caledonia. LITHOS 2013, 178, 24-39, doi:10.1016/j.lithos.2013.02.002.

73. Klein, F.; Bach, W.; Jöns, N.; McCollom, T.; Moskowitz, B.; Berquó, T. Iron partitioning and hydrogen generation during serpentinization of abyssal peridotites from $15^{\circ} \mathrm{N}$ on the Mid-Atlantic Ridge. Geochim. Cosmochim. Acta 2009, 73, 6868-6893, doi:10.1016/j.gca.2009.08.021.

74. Frost, B.R.; Beard, J.S.; Frost, R.B.; Beard, J.S.; Frost, B.R.; Beard, J.S.; Frost, R.B.; Beard, J.S. On silica activity and serpentinization. J. Petrol. 2007, 48, 1351-1368, doi:10.1093/petrology/egm021.

75. Putnis, A. Mineral Replacement Reactions. Rev. Mineral. Geochemistry 2009, 70, 87-124, doi:10.2138/rmg.2009.70.3.

76. Evans, B.W. The Serpentinite Multisystem Revisited: Chrysotile Is Metastable. Int. Geol. Rev. 2004, 46, 479-506, doi:10.2747/0020-6814.46.6.479.

77. Freyssinet, P.; Butt, C.R.M.; Morris, R.C.; Piantone, P. Ore-forming processes related to lateritic weathering. Econ. Geol. 100th Anniv. Vol. 2005, 1, 681-722.

78. Bach, W.; Paulick, H.; Garrido, C.J.; Ildefonse, B.; Meurer, W.P.; Humphris, S.E. Unraveling the sequence of serpentinization reactions: Petrography, mineral chemistry, and petrophysics of serpentinites from MAR $15^{\circ} \mathrm{N}$ (ODP Leg 209, Site 1274). Geophys. Res. Lett. 2006, 33, 4-7, doi:10.1029/2006GL025681.

79. Pokrovsky, O.S.; Schott, J. Experimental study of brucite dissolution and precipitation in aqueous solutions: surface speciation and chemical affinity control. Geochim. Cosmochim. Acta 2004, 68, 31-45, doi:10.1016/S0016-7037(03)00238-2.

80. Klein, F.; Humphris, S.E.; Bach, W. Brucite formation and dissolution in oceanic serpentinite. Geochemical Perspect. Lett. 2020, 1-5, doi:10.7185/geochemlet.2035.

81. Templeton, A.S.; Ellison, E.T. Formation and loss of metastable brucite: does Fe(II)-bearing brucite support microbial activity in serpentinizing ecosystems? Philos. Trans. A. Math. Phys. Eng. Sci. 2020, 378, 20180423, doi:10.1098/rsta.2018.0423.

82. Konrad-Schmolke, M.; Halama, R.; Wirth, R.; Thomen, A.; Klitscher, N.; Morales, L.; Schreiber, A.; Wilke, F.D.H. Mineral dissolution and reprecipitation mediated by an amorphous phase. Nat. Commun. 2018, 9, doi:10.1038/s41467-018-03944-z.

83. Barnes, I.; Lamarche, V.C.; Himmelberg, G. Geochemical evidence of present-day serpentinization. Science (80-. ). 1967, 156, 830-832, doi:10.1126/science.156.3776.830.

84. Barnes, I.; O'Neil, J.R.; Trescases, J.J. Present day serpentinization in New Caledonia, Oman and Yugoslavia. Geochim. Cosmochim. Acta 1978, 42, 144-145, doi:10.1016/0016-7037(78)90225-9.

85. Neal, C.; Stanger, G. Hydrogen generation from mantle source rocks in Oman. Earth Planet. Sci. Lett. 1983, 66, 315-320, doi:10.1016/0012-821X(83)90144-9.

86. Cardace, D.; Meyer-dombard, D.R.A.R.; Woycheese, K.M.; Arcilla, C.A.; Brazelton, W.; Carolina, E. Feasible metabolisms in high pH springs of the Philippines. Front. Microbiol. 2015, 6, 1-17, doi:10.3389/fmicb.2015.00010.

87. Streit, E.; Kelemen, P.; Eiler, J. Coexisting serpentine and quartz from carbonate-bearing serpentinized peridotite in the Samail Ophiolite, Oman. Contrib. to Mineral. Petrol. 2012, 164, 821-837, doi:10.1007/s00410-012-0775-z.

88. Kelemen, P.B.; Matter, J.; Streit, E.E.; Rudge, J.F.; Curry, W.B.; Blusztajn, J. Rates and mechanisms of mineral carbonation in peridotite: Natural processes and recipes for enhanced, in situ CO2 capture and storage. Annu. Rev. Earth Planet. Sci. 2011, 39, 545-576, doi:10.1146/annurev-earth-092010-152509.

89. Klein, F.; Bach, W.; McCollom, T.M. Compositional controls on hydrogen generation during serpentinization of ultramafic rocks. Lithos 2013, 178, 55-69, doi:10.1016/j.lithos.2013.03.008.

90. Klein, F.; Le Roux, V. Quantifying the volume increase and chemical exchange during serpentinization. Geology 2020, 48, 552-556, doi:10.1130/G47289.1.

91. O'Hanley, D.S. Solution to the volume problem in serpentinization. Geology 1992, 20, 705-708, doi:10.1130/00917613(1992)020<0705:STTVPI 2.3.CO;2. 